\title{
Petrografia e Geoquímica do Complexo Charnockítico de Aimorés: Um Exemplo de Plutonismo Pós-orogênico do Cinturão Araçuaí/Ribeira
}

\section{Petrography and Geochemistry of the Aimorés Charnockitic Complex: An Example of Post-orogenic Plutonism of the Araçuaí/Ribeira Belt}

\author{
Fernando Machado de Mello' (fermamll@ufrri.br),Rômulo Machado² (rmachado@usp.br), \\ Essaid Bilal33 (bilal@emse.fr) \\ 'Departamento de Geociências - Instituto de Agronomia - UFRRJ \\ BR 465 - Km 07, CEP 23890-000, Seropédica, RJ, BR \\ ${ }^{2}$ Departamento de Geologia Sedimentar e Ambiental - Instituto de Geociências - USP, São Paulo, SP, BR \\ 3École Nationale Supérieure des Mines de Saint-Étienne, Saint-Étienne, FR
}

Recebido em 12 de novembro de 2009; aceito em 21 de outubro de 2010

\section{RESUMO}

O Complexo Aimorés corresponde a um corpo multi-intrusivo anelar com cerca de $150 \mathrm{~km}^{2}$ de exposição. Possui características pós-orogênicas e exibe zonas de misturas de magma no contato e no interior do corpo. O complexo é constituído de monzodioritos no centro, com um anel intermediário de charnockitos, circundado por granodioritos. Há ocorrências menores de leucogranitos com granada. São abundantes enclaves básicos e intermediários, de diferentes tamanhos e formas. O contato com a encaixante é de alto ângulo e mostra-se concordante e discordante. Nas rochas encaixantes predominam gnaisses de fácies anfibolito a granulito. As diversas fácies do complexo são meta-aluminosas, exceto os leucogranitos e os megaenclaves que são peraluminosos. O índice de saturação em alumina é ao redor de 1 e o índice de agpaicidade $((\mathrm{Na}+\mathrm{K}) / \mathrm{Al})$ situa-se entre 0,45 e 0,77 . Nos diagramas de Harker, a correlação negativa de $\mathrm{CaO}, \mathrm{MgO}, \mathrm{Fe}_{2} \mathrm{O}_{3}, \mathrm{TiO}_{2}$ e $\mathrm{P}_{2} \mathrm{O}_{5}$ pode ser explicada principalmente pelo fracionamento de piroxênio e feldspato. A razão $\mathrm{MgO} / \mathrm{TiO}_{2}$ próxima a 1 é compatível com granitoide tardi a pós-colisional. As razões $\mathrm{Ba} / \mathrm{Sr}, \mathrm{Zn} / \mathrm{MgO}, \mathrm{Sr} / \mathrm{Rb}$ e Ba/ $\mathrm{Rb}$ indicam fracionamento importante promovido inicialmente por piroxênio e plagioclásio e depois por anfibólio, biotita e feldspato de potássio. Os dados geoquímicos parecem refletir a combinação de processos de cristalização fracionada e/ou de contaminação crustal e de mistura de magmas.

Palavras-chave: Charnockito; Geoquímica; Petrografia; Mistura de magmas; Pós-colisional.

\section{ABSTRACT}

The Aimorés Complex is an inversely zoned multistage ring-like structure which crops out over about $150 \mathrm{~km}^{2}$ and was intruded approximately 500 Ma years ago, during the post-collision event related to Araçuai-Ribeira Fold Belt. This complex consists of a monzodioritic core with hypersthene, and a charnockitic intermediary ring encircled by granodiorites. The contact between core and rim is marked by a mingled/mixed zone, where small occurrences of garnet-granite were also found. Abundant enclaves of different shapes and sizes occur showing circular, diffuse and sharp contacts with the groundmass. The contact with the country rocks is sharp and sub-vertical, varying from concordant to discordant and presenting dips toward the intrusion. The enclosing rocks are orthogneiss, which have experienced high-amphibolite to granulite-facies metamorphism. Most of the facies of the complex are metaluminous, except for the large enclaves embedded in the inner portion, which are peraluminous. The aluminium saturation index is approximately 1 and the agpaitic index $((\mathrm{Na}+\mathrm{K}) / \mathrm{Al})$ ranges from 0.45 to 0.77. The negative correlation of $\mathrm{CaO}, \mathrm{MgO}, \mathrm{Fe}_{2} \mathrm{O}_{3}, \mathrm{TiO}_{2}$ e $\mathrm{P}_{2} \mathrm{O}_{5}$ in the Harker diagram can be explained by pyroxene and feldspar fractionation. The $\mathrm{MgO} / \mathrm{TiO}_{2}$ ratio close to 1 and the tectonic discrimination diagrams are compatible with postcollisional granitoids, as well as the sum of $\mathrm{Zr}, \mathrm{Nb}, \mathrm{Ce}$ and $\mathrm{Y}(500-1.000 \mathrm{ppm})$. The $\mathrm{Ba} / \mathrm{Sr}, \mathrm{Sr} / \mathrm{Rb}, \mathrm{Ba} / \mathrm{Rb}$ and $\mathrm{Zn} / \mathrm{MgO}$ ratios indicate that there was initially fractionation by pyroxene and plagioclase, followed later by fractionation by amphibole, biotite and K-feldspar. Geochemical data probably reflects the combination of crystal fractionation and/or crustal contamination and magma mingling/mixing processes.

Keywords: Charnockite; Geochemistry; Petrography; Magma mingling/mixing; Post-collisional. 


\section{INTRODUÇÃO}

Os granitos são excelentes indicadores do ambiente tectônico e também excelentes marcadores da deformação, razão pela qual o seu estudo fornece informações importantes sobre a evolução tectônica de cinturões dobrados. Sabe-se que existe correlação tectônica entre tipos diferentes de granitos e seu ambiente tectônico, assim como o magmatismo associado a um determinado cinturão orogênico não é exatamente idêntico ao de outro, pois cada cinturão orogênico possui características próprias, ou seja, possui uma evolução tectônica única, que é o resultado da combinação de vários fatores, tais como idade do orógeno, constituição do substrato do seu arco, situação espaço-tempo orogênico, espessura do pacote sedimentar, natureza das grandes falhas ou das zonas de cisalhamento associadas, regime bárico do metamorfismo regional, idade da sua margem continental e da litosfera oceânica que foi subductada (Pitcher, 1982, 1987).

A relação do magmatismo granítico em função dos estágios orogênicos permite distinguir quatro tipos principais de granitos: pré-colisionais, sin-colisionais, tardi-colisionais e pós-colisionais. Os granitos pré-colisionais são associados com a subducção de uma litosfera oceânica e correspondem a granitos tipo-I Cordilherano, a exemplo dos batólitos andinos e da costa oeste americana; os granitos sin-colisionais vinculam-se ao espessamento crustal e correspondem ao magmatismo peraluminoso tipo-S mais volumoso de um Orógeno, sendo também referido como magmatismo Hercínico; os granitos tardi-colisionais associam-se em geral a grandes zonas de cisalhamento transcorrentes e refletem ainda os efeitos compressivos da fase orogênica anterior, enquanto os granitos pós-colisionais são formados em ambiente tectônico claramente distensional e caracterizam-se por um magmatismo cálcio-alcalino alto-K/alcalino e correspondem ao magmatismo tipo-I Caledoniano de muitos autores (Pitcher, 1997; Pearce, Harris, Tindle, 1984; Harris, Pearce, Tindle, 1986; Sylvester, 1998).

O Complexo Aimorés situa-se na região do baixo vale do Rio Doce, no Estado de Minas Gerais, próximo à divisa com o Espírito Santo (Figura 1). Em termos geológicos, a área estudada acha-se inserida em rochas metamórficas de alto grau, correlacionáveis ao Complexo Paraíba do Sul (Vieira et al., 1993). Em termos geotectônicos, a área estudada faz parte do segmento setentrional da Faixa/Cinturão Ribeira (sensu Almeida et al., 1973; Hasui, Carneiro, Coimbra, 1975) ou meridional da Faixa Araçuaí (sensu Pedrosa Soares e Wiedemann-Leonardos, 2000; Pedrosa Soares et al., 2001) e da Província Mantiqueira Setentrional (Almeida e Hasui, 1984).

Os complexos charnockíticos do Espírito Santo (Lagoa Preta, Várzea Alegre, Santa Angélica, Castelo, dentre outros), similares ao complexo charnockítico aqui estudado, têm sido classificados como tardi-orogênicos (Medeiros, Wiedemann-Leonardos, Vriend, 2000; Pedrosa Soares e Wiedemann-Leonardos, 2000; Wiedemann et al., 2002), tardi- a pós-tectônicos/tardi a pós-orogênicos (Siga Jr., 1986; Wiedemann, 1993; Bilal et al., 1998; Mendes, Wiedemann, McReath, 1999; Mendes, Wiedemann, McReath, 2005) e pós-colisional (Figueiredo e Campos Neto, 1993; Wiedemann et al., 2002; Campos Neto e Figueiredo, 1995).

Os complexos charnockíticos do Espírito Santo apresentam em comum os seguintes aspectos: 1. contato em alto ângulo com as rochas encaixantes, 2. foliação magmática interna, 3. estrutura concêntrica e em geral com zonamento inverso (Santa Angélica, Castelo, Mimoso do Sul, Várzea Alegre e Aimorés), 4. gabros/dioritos na parte central e granitos porfiríticos (mega) e charnockitos na periferia, 5. são comuns zonas com feições de mistura e hibridização de magmas (Wiedeman et al., 2002; Wiedemann, 1993; Mendes et al., 1997; Mendes, Wiedemann, McReath, 1999; Mendes, Wiedemann, McReath, 2005; Medeiros, Wiedemann-Leonardos, Vriend, 2000; Medeiros, Wiedemann, Mendes, 2001; Mello, 2000).

Estes complexos apresentam em geral as seguintes características: 1. magmatismo bimodal; 2. estrutura concêntrica inversamente zonada - rochas em geral básicas no centro e ácidas na parte externa; 3 . zonas de hibridização de magmas; 4. toleííticos, cálcio-acalinos e alcalinos; 5. foliação magmática interna; 6. contatos em alto ângulo com as encaixantes; 7. colocação dos corpos em níveis profundos da crosta (15 a $20 \mathrm{~km})$; 8. encaixados em rochas metamórficas de alto grau (Wiedemann, 1993; Wiedemann et al., 2002).

A origem das rochas graníticas desses complexos envolve um modelo com geração expressiva de magma em pelo menos dois estágios: um com geração de magma derivado do manto e outro, derivado da crosta (Offman e Weber-Diefenbach, 1989; Wiedemann, Mendes, Ludka, 1995). Os modelos envolvem underplating de magma basáltico proveniente da fusão parcial de um manto enriquecido que ascendeu até a base da crosta, delaminação com quebra e ascensão do manto litosférico, substituição do manto litosférico pelo manto astenosférico quente e fusão parcial da crosta com produção de líquidos graníticos e monzograníticos, seguindo-se a interação com magmas básicos e produção do magmatismo bimodal (Mendes, Wiedemann, McReath, 1999; Wiedemann et al., 2002).

São apresentados e discutidos neste trabalho a petrografia e geoquímica (elementos maiores, traço e terras raras) de 25 amostras do Complexo Aimorés com o objetivo de caracterizar a natureza do seu magmatismo e classificá-lo em termos tectônicos, bem como comparar os resultados 

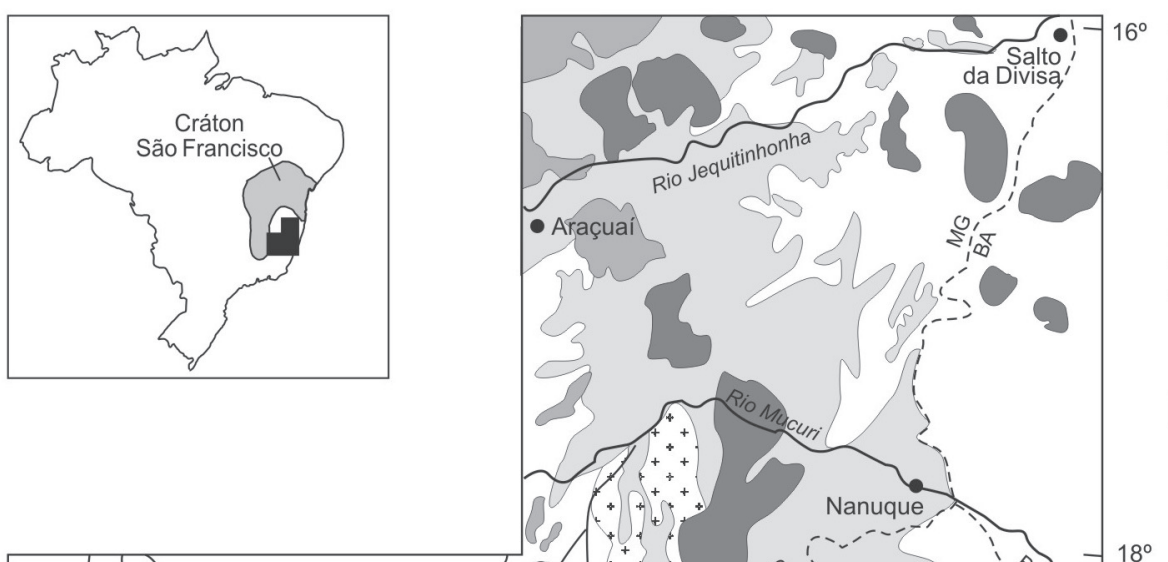

ORÓGENO ARAÇUAí

Cambriano

$\square$ Suíte G5: tipo I, 520-490 Ma

Suíte G4: tipo S, 535-500 Ma

Neoproterozoico

$\square$ Suíte G2: tipo S, 582-560 Ma (inclui corpos da Suíte G3)

$+{ }^{+}+$Suíte G1: tipo I, 630-585 Ma

Embasamento e cobertura não diferenciados

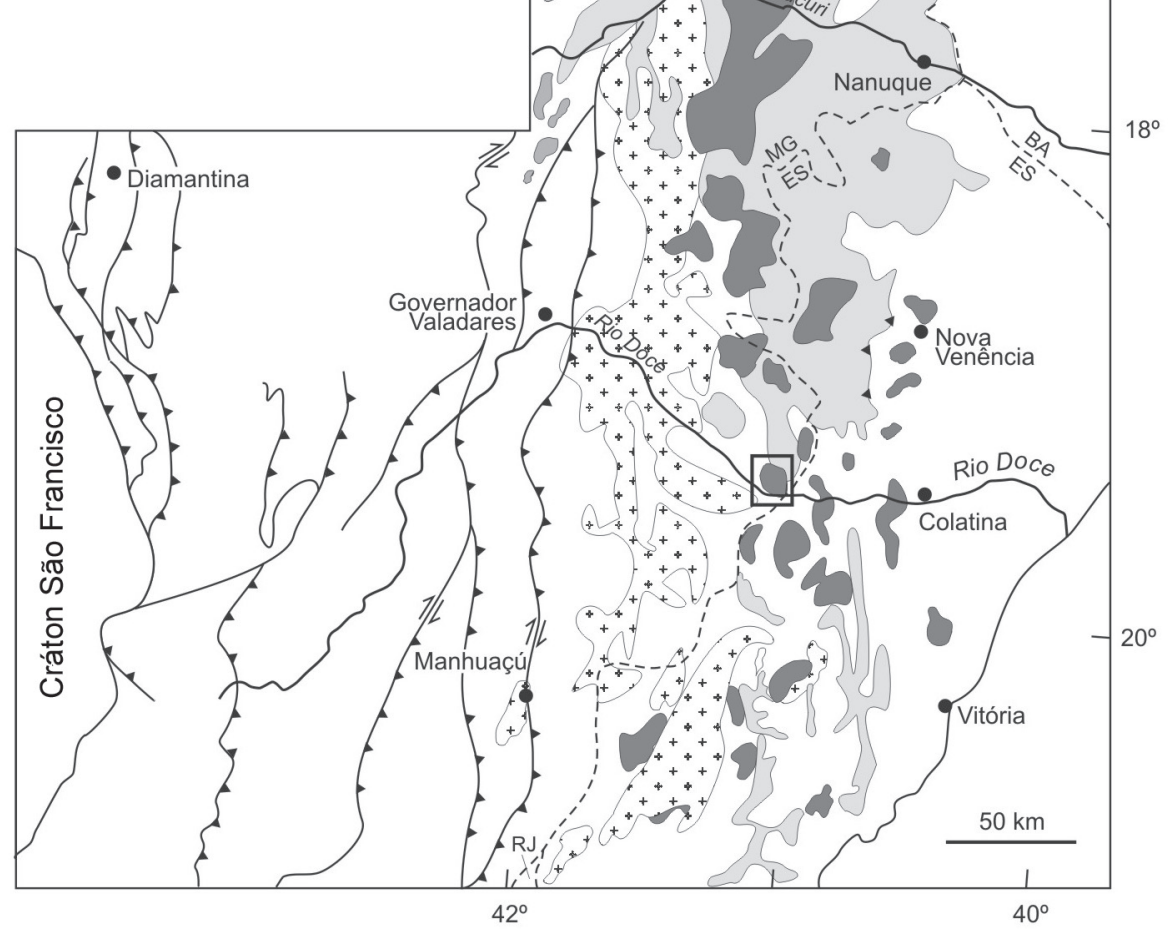

Figura 1. Mapa de distribuição das rochas graníticas brasilianas e cambrianas da Faixa Araçuaí (modificado de Pedrosa-Soares et al., 2007).

aqui obtidos com os de complexos charnockíticos similares que ocorrem no Espírito Santo, estudados por outros autores (Wiedemann, 1993; Wiedemann, Mendes, Ludka, 1995; Wiedemann et al., 1997, 2002; Mendes et al., 1997; Mendes, Wiedemann, McReath, 1999; Mendes et al., 2005).

\section{TRABALHOS ANTERIORES}

Após o trabalho pioneiro de Brajnikov (1955) que, ao descrever pela primeira vez rochas charnockíticas na região do Vale do Rio Doce, considera para elas uma origem metamórfica a partir da granitização de noritos, classificando-as de charnockito gnaisses. Guimarães (1956), ao estudar petrograficamente alguns corpos, atribui-lhes ori- gem magmática e considera que eles sofreram apenas uma fase de metamorfismo.

Pinheiro, Biondi e Pinheiro (1978), ao descreverem a petrografia dos maciços Aimorés, Itapina, Itaguaçu e Itanhomi, concluíram que tais rochas podem ser classificadas segundo sua mineralogia, textura e estrutura nos seguintes grupos: 1. Granolitos, 2. Granoblastitos, 3. Granulitos Gabroides, Noríticos e Piroxeníticos.

Seguem-se os projetos de cartografia geológica regional - escalas 1: 250.000 e 1:1000.000 -, desenvolvidos, respectivamente, pela CPRM - Serviço Geológico do Brasil (Projeto Jequitinhonha) e pelo Radambrasil (Folha Rio Doce - SE-24) (Fontes et al., 1978; Silva et al., 1987). Tais projetos já contemplam a cartografia do Complexo Aimo- 
rés e de outros charnockitos relacionados, e contêm uma descrição geral das unidades e uma tentativa de posicionamento temporal das mesmas. Silva et al. (1987) consideram essas rochas como produto da anatexia dos complexos Juiz de Fora e Pocrane. Os complexos charnockíticos são considerados sin a tardi-tectônicos ao Ciclo Brasiliano.

O Projeto Jequitinhonha agrupa as rochas da região em quatro complexos: 1. Complexo Gnássico-Migmatítico; 2. Complexo Gnaisse Kinzigítico; 3. Complexo Charnockítico, 4. Complexo Granitoide. Os três primeiros foram considerados de idade arqueana a proterozoico inferior, enquanto o último, do Proterozoico indiviso. Fontes et al. (1978) sugerem o truncamento da foliação principal (NNE-SSW a NW-SE) por um sistema de falhas subverticais com orientação N60E (Lineamento Ipanema-Nova Venécia).

O Projeto Rio Doce reúne as unidades acima nos complexos Juiz de Fora, Pocrane e Gnaisse Piedade (Silva et al., 1987) e considera-os de idade arqueana, retrabalhados durante os ciclos Transamazônico e Brasiliano.

O Programa de Levantamento Geológico Básico do Brasil - PLGB, em escala 1:100.000, da CPRM, agrupa as rochas da região estudada em sete unidades litoestratigráficas pré-cambrianas/paleozoicas: 1. Complexo Juiz de Fora; 2. Complexo Paraíba do Sul; 3. Complexo São Tomé, incluindo rochas supracrustais; 4. Granulito tipo Mascarenhas e Gnaisse enderbítico tipo Santa Tereza, ambos portadores de feições plutônicas e intrusivos no Complexo Paraíba do Sul; 5. Ortognaisses de dimensões batolíticas; 6. suítes intrusivas granitoides cambrianas, tardi a pós-transcorrências; 7. corpos de intrusivas ácidas menores, possivelmente ordovicianas (Vieira et al., 1993).

Os autores descrevem para as rochas da região cinco fases de deformação: as duas primeiras $\left(D_{n}\right.$ e $\left.D_{1}\right)$ relacionadas com a tectônica tangencial; as duas seguintes $\left(\mathrm{D}_{2} \mathrm{e}\right.$ $\mathrm{D}_{3}$ ) sendo responsáveis pela geração de dobras suaves e de grande amplitude, com eixos NNE $\left(\mathrm{D}_{2}\right)$ e $\mathrm{NW}\left(\mathrm{D}_{3}\right)$, e a última fase $\left(\mathrm{D}_{4}\right)$ sendo responsável por extensas zonas de cisalhamento de alto ângulo, a exemplo do Lineamento Transcorrente de Guaçuí, com orientação NNE-SSW, situado a sul da cidade de Baixo Guandu.

Trabalhos de cartografia geológica realizados a leste de Aimorés, em escala 1:100.000, pela CPRM (Tuller, 1993), permitiram separar quatro unidades: 1. Granulito Mascarenhas; 2. Suíte Aimorés; 3. Complexo Paraíba do Sul; 4. Granito Colatina. A suíte Aimorés, representada na área pelo maciço de Itapina, é caracterizada por hiperstênio-granito porfirítico, microclina-granito porfirítico e quartzo diorito. O metamorfismo regional atingiu o grau alto e são distinguidas quatro fases de deformação: a primeira, tangencial, associa-se ao metamorfismo regional em fácies anfibolito alto, a segunda associa-se às dobras abertas e fechadas com orientação N-S e NNE-SSW e superfícies axiais verticais, a terceira, com dobras abertas a suaves de orientação E-W, e a quarta fase, de natureza extensional, é relacionada com a geração de estruturas rúpteis (falhas), preenchidas por rochas básicas (Tuller, 1993).

Nalini (1997) descreve entre Galileia e Colatina foliação sub-horizontal na região de Baixo Guandu/Aimorés, influenciada provavelmente pela intrusão do Complexo Aimorés. O complexo, no entanto, possui foliação média N10W/60NE. Descreve ainda entre Baixo Guandú e Colatina uma foliação subvertical com mergulhos fortes para leste, associada às dobras apertadas e isoclinais com lineação mineral orientada entre N10-30E e caimentos entre 10 e $30^{\circ}$. Ressalta nesta região a forte influência da zona de cisalhamento de Vitória.

Investigações microestruturais e de eixos-C de quartzo realizadas entre Aimorés (MG) e Colatina (ES) mostram deformações sob temperaturas entre 550 e $700^{\circ} \mathrm{C}$ (Karniol e Machado, 2004). Os autores descrevem cordierita associada aos gnaisses aluminosos e relacionam o regime metamórfico de baixa pressão nestas rochas ao estágio de exumação.

Estudos estruturais conduzidos nesta mesma região caracterizaram duas direções principais da foliação: uma N-S a NNW-SSE e outra NE-SW. A primeira foliação possui mergulhos altos a baixos para leste e nordeste, e a segunda apresenta mergulhos intermediários a altos (Karniol e Machado, 2004). Os autores descrevem em charnockito dos arredores de Itapina estruturas magmáticas compressivas com movimentos de topo para SW e relacionam esta rocha aos maciços charnockíticos da região (Aimorés, Lagoa Preta, entre outros). Salientam a semelhança entre a orientação da foliação magmática do charnockito com a foliação metamórfica das encaixantes- granulitos no contato oeste e gnaisses no contato leste - e interpretam isso como devido à reativação de estruturas mais antigas durante o alojamento do referido corpo. São descritas ainda nos granodioritos e tonalitos encaixantes do Complexo Aimorés lineações verticalizadas, atribuídas à colocação do mesmo e consideradas de mesma idade.

Mello (2000), com base em estudos do Complexo Aimorés e dados isotópicos sobre os complexos charnockíticos do estado do Espírito Santo e leste de Minas Gerais, sugere um zonamento longitudinal dos mesmos - pelo menos a partir do médio vale do Rio Doce para sul - sentido em que os charnockitos são considerados de colocação mais profunda, mais evoluídos geoquimicamente e, aparentemente, mais jovens. A explicação do autor para isso é atribuída a uma crosta mais espessa para sul.

O Complexo Aimorés apresenta conteúdos elevados em $\mathrm{HfO}_{2}$ nos zircões, situando-se entre 1,3 a $1,9 \%$, com os valores mais elevados $(\sim 1,8 \%)$ sendo encontrados na unidade dos Granada-Granitos (Mello, 2000). 
Dados geotermobarométricos obtidos para as rochas charnockíticas dos complexos Várzea Alegre e Santa Angélica (situados a sul de Aimorés e Lagoa Preta), a partir da distribuição estrutural do $\mathrm{Al}$ em anfibólio cálcico e no par anfibólio-plagioclásio, forneceram valores de pressão no intervalo de 5,7 $\pm 0,6$ kbar a 11,47 $\pm 0,6 \mathrm{kbar}$ (Mendes, Wiedemann, McReath, 1999), enquanto para o Complexo Aimorés foram obtidas pressões entre 5 e 11 kbar e temperaturas entre $700^{\circ} \mathrm{C}$ e $1000^{\circ} \mathrm{C}$, sugerindo profundidade de alojamento entre 15 e $20 \mathrm{~km}$ (Mello et al., 2007). A porção menos diferenciada do complexo forneceu pressões entre $4,9 \pm 0,6$ kbar a $6,4 \pm 0,6$ kbar, enquanto os charnockitos forneceram pressões ligeiramente menores, entre 4,4 $\pm 0,6$ kbar e 5,8 $\pm 0,6$ kbar. Os charnockitos do Complexo Lagoa Preta dão pressões pouco mais elevadas, entre 5,8 \pm 0,6 kbar e 6,6 $\pm 0,6 \mathrm{kbar}$, com a sua colocação ocorrendo a pressão de $6 \pm 0,4$ kbars e temperatura superior a $870^{\circ} \mathrm{C}$ (Mello et al., 2007).

Estudos termocronológicos e geobarométricos realizados em gnaisses migmatíticos aluminosos da região do vale do rio Doce mostram valores máximos de pressão a $6,5 \pm 0,5 \mathrm{kbar}$ e de temperatura a $820 \pm 30^{\circ} \mathrm{C}$, com o metamorfismo de alto grau tendo ocorrido entre $\sim 530$ e $\sim 480 \mathrm{Ma}$ (Munhá et al., 2005). O modelamento dos autores mostra um resfriamento rápido a partir de $480 \mathrm{Ma}$ $\left(<10 \mathrm{Ma}\right.$ a $\left.\geq 60^{\circ} \mathrm{C} / \mathrm{km}\right)$ e depois extremamente lento entre $\sim 470$ e 420 Ma.

\section{GRANITOIDES BRASILIANOS DO VALE DO RIO DOCE}

Poucos são os trabalhos de síntese regional sobre os granitoides brasilianos da região do vale do rio Doce, sendo mais comuns trabalhos relacionados ao estudo de maciços isolados e que abordam em geral aspectos petrográficos, litogeoquímicos, e mais raramente geocronológico e estrutural (Siga Jr., 1986; Wiedemann et al., 2002; Wiedemann, Mendes, Ludka, 1995; Figueiredo e Campos Neto, 1993; Wiedemann, 1993; Ludka, Wiedemann, Töfner, 1998; Mendes et al., 1997, 2005; Nalini, 1997; Bilal et al., 1998; Pedrosa Soares e Wiedemann-Leonardos, 2000; Martins, 2000; Martins et al., 2004; Nalini, Machado, Bilal, 2005, 2008).

Siga Jr. (1986), com base em datações Rb/Sr, divide o magmatismo granítico da Faixa Araçuaí em três grupos de granitos: 1. sin a tardi-tectônicos (650 a $550 \mathrm{Ma}$ ), 2. tardi a pós-tectônicos (550 a $500 \mathrm{Ma})$; 3. pós-tectônicos a anorogênicos (500 a $450 \mathrm{Ma})$.

Os trabalhos de cartografia geológica do Projeto de Levantamento Geológico Básico (PLGB) em escala $1: 100.000$, conduzidos pela CPRM na região do vale do Rio Doce, dividem o magmatismo granítico em três grupos deformacionais: 1. pré a sin-tangencial; 2. sin-trans- corrente; 3. pós-transcorrente (Féboli, 1993; Tuller, 1993). Os complexos charnockíticos da região (Aimorés, Lagoa Preta, Várzea Alegre, dentre outros) foram incluídos no terceiro grupo.

O magmatismo granítico do Espírito foi relacionado a um arco magmático brasiliano - Arco Magmático (ou Orogênese) Rio Doce - e dividido por Figueiredo e Campos Neto (1993) e Campos Neto e Figueiredo (1995) em três grupos: 1. pré-colisional (590 a $570 \mathrm{Ma}), 2$. sin-colisional (560 a $530 \mathrm{Ma})$, 3. pós-colisional (520 e $480 \mathrm{Ma})$; e por Wiedemann (1993) em dois grupos: 1. sin-orogênico (590 a $580 \mathrm{Ma}), 2$. tardi a pós-orogênico (520 a $450 \mathrm{Ma})$.

Bilal et al. (1998) reconhecem no vale do Rio Doce quatro grupos de granitos com base em idades principalmente U/Pb: 1. pré-tectônicos - 595 Ma; 2. sin-tectônicos - 582 Ma; 3. tardi a pós-tectônicos - 537 a 520 Ma; 4. pós-tectônicos - $511 \mathrm{Ma}$. O penúltimo grupo engloba os complexos intrusivos Aimorés e Ibituba-Itapina.

Pedrosa-Soares e Wiedemann-Leonardos (2000) dividem os granitos da Faixa Araçuaí em cinco suítes (da mais antiga- G1 para a mais nova-G5): G1- pré-colisional (625 - $595 \mathrm{Ma}$ ); G2- sin-colisional (591 - $575 \mathrm{Ma}$ ); G3- tardi a pós-colisional (575 - $560 \mathrm{Ma})$; G4 e G5 - tardi a pós-orogênica (535 - $490 \mathrm{Ma})$, nesta última sendo incluídos os complexos charnockíticos (Aimorés, Caladão, Várzea Alegre, Venda Nova etc.).

Os intervalos de idade propostos para esse magmatismo são os seguintes: 535 a $480 \mathrm{Ma}$ (Pedrosa-Soares e Wiedemann-Leonardos, 2000), 520 a 480 Ma (Figueiredo e Campos Neto, 1993; Campos Neto e Figueiredo, 1995) e 520 a 450 Ma (Wiedemann, 1993). São disponíveis idades $\mathrm{U} / \mathrm{Pb}$ (TIMS) e $\mathrm{Pb} / \mathrm{Pb}$ (evaporação) em zircão para os complexos Santa Angélica, $513 \pm 8$ Ma (Söllner et al., 1987); Caladão/Padre Paraíso, $519 \pm 2$ Ma (Noce et al., 1999; Noce, Macambira, Pedrosa-Soares, 2000); Várzea Alegre, $498 \pm 4,9 \mathrm{Ma}$ (Mendes et al., 2005) e 498 $\pm 35 \mathrm{Ma}$ (Mello, 2000).

No médio vale do Rio Doce foram também obtidas idades U/Pb em zircão (diluição isotópica) de 594 Ma para a Suíte Galileia e de 584 Ma para a Suíte Urucum (Nalini, 1997; Nalini et al., 2000).

Os dados geoquímicos destes maciços sugerem três séries magmáticas: toleítica, cálcio-alcalina e alcalina (Wiedemann, 1993; Wiedemann et al., 2002). A série cálcio-alcalina, a mais expressiva dos plútons estudados (de $\sim 90 \%$ ), é meta-aluminosa, alto-K, e foi originada numa crosta continental, porém com importante contribuição de um manto enriquecido (Mendes et al., 1997; Mendes, Wiedemann, McReath, 1999; Ludka, Wiedemann, Töfner, 1998; Medeiros, Wiedemann, Mendes, 2001; Wiedemann et al., 2002).

Os dados isotópicos do Complexo Várzea Alegre mostram razões ${ }^{87} \mathrm{Sr} /{ }^{86} \mathrm{Sr}$ dominantes entre 0,708 e 0,7011 e 
$\varepsilon_{\mathrm{Nd}(\mathrm{t})}$ negativos $(-4,7$ a $-8,4)$, interpretados como resultantes de participação crustal (Medeiros, Wiedemann-Leonardos, Vriend, 2000; Mendes et al., 2005). As rochas intermediárias e os charnockitos apresentam valores similares de $\varepsilon_{\mathrm{Nd}(t)}$, enquanto as básicas exibem valores levemente menos negativos.

\section{Complexo Aimorés}

O Complexo Aimorés caracteriza-se por uma estrutura interna de alto ângulo, com predomínio de mergulhos para o interior do corpo e presença de foliação de fluxo magmático nos granodioritos porfiríticos (Figura 2A). O complexo é constituído por rochas básicas e intermediárias na sua parte central e por rochas progressivamente mais ácidas em direção à porção externa da estrutura. Assinalam-se também ocorrências de granada-granitos (leucogranitos) que afloram no interior e na parte externa do complexo.

A presença na imagem Landsat de feições lineares paralelas NE, observadas somente na parte sudeste da mesma (Figura 2B), sem continuidade aparente nas rochas encaixantes, deve corresponder a estruturas mais jovens. Estas estruturas são de difícil reconhecimento em campo, sendo, no entanto, marcadas pela orientação de drenagens. O lineamento mais marcante na imagem Landsat é uma zona de cisalhamento dúctil de alto ângulo com direção próxima de E-W (N80W), observada na parte norte e noroeste do corpo, a sul das cristas mais elevadas do granito porfirítico. A análise das principais componentes das bandas espectrais foi extraída da "PC1", que contém a maior parte das informações correlacionáveis das bandas principais, representando o "albedo". Trata-se de uma imagem com textura mais rica em informações que, após a aplicação de filtros de convolução Laplacianos ( 5 x 5) do tipo passa altas (High Pass Filters), permite realçar estruturas da parte interna do plúton, onde os afloramentos são escassos, como pode ser observado na Figura 2B. Notam-se, na parte sudoeste, feições lineares que representam a orientação da foliação magmática dos granodioritos.

No mapa faciológico efetuado por Mello (2000) são separadas as principais unidades do complexo, a saber:

Hiperstênio Monzodioritos: ocupam principalmente a parte central do mapa (Figura 2A). Segundo a classificação de charnockitos de Streckeisen (1974), correspondem a jotunitos e associam-se às rochas básicas (noritos e hy-dioritos) e rochas ricas em sílica (opdalitos e enderbitos), com algumas delas sendo ricas em titanita (titanita-quartzo-dioritos). No diagrama de classificação de rochas ígneas de O'Connor (1965), estas rochas situam-se no campo dos granodioritos, próximo ao limite de campo com os tonalitos (Figura 3). São rochas com textura heterogranular (Figura 4A), maciças, que podem exibir em afloramento es-

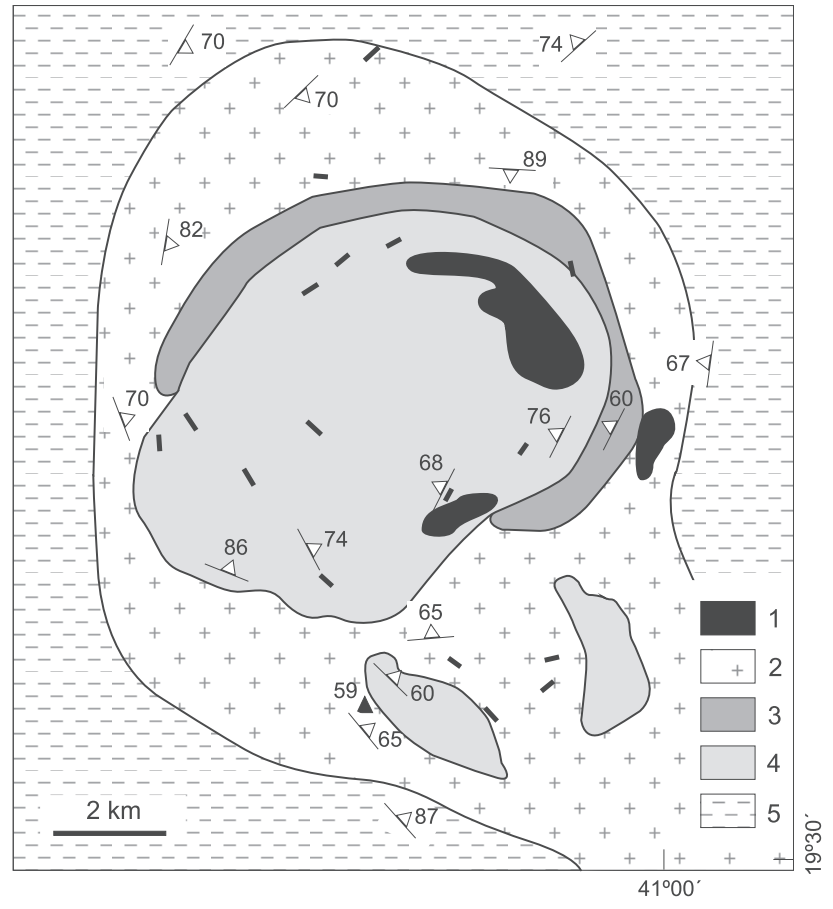

Figura 2A. Mapa geológico simplificado do Complexo Charnockítico Aimorés: 1. granada-granitos; 2. granodioritos porfiríticos; 3 . charnockito; 4 . hiperstênio-monzodiorito e titanita-quartzo-monzodiorito; 5. embasamento gnáissico-granítico indiscriminado.

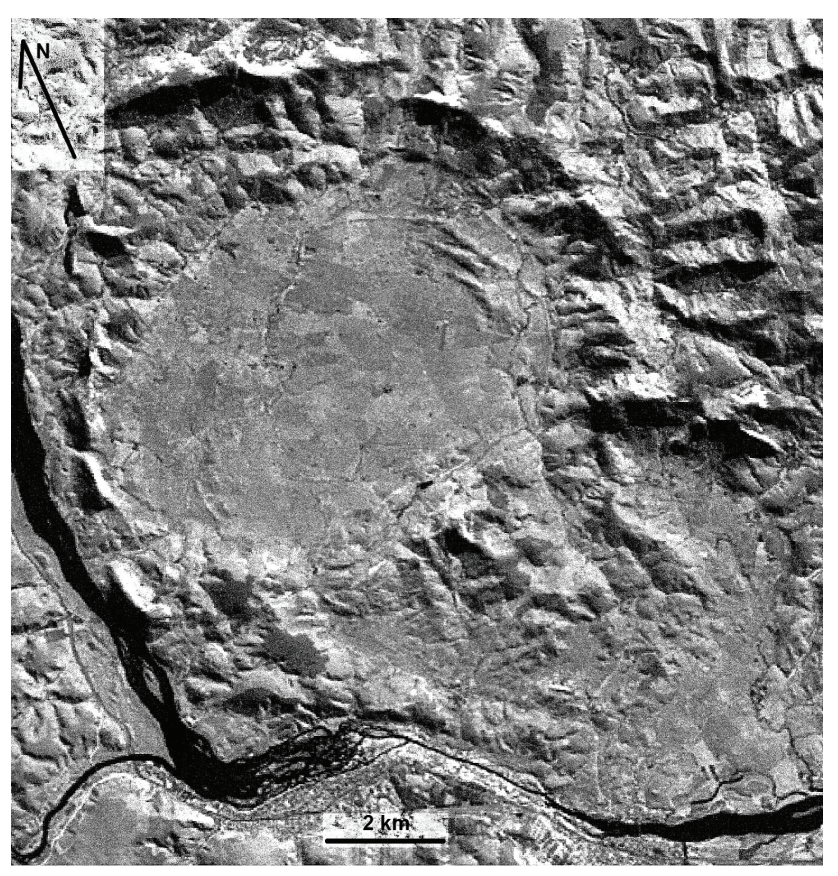

Figura 2B. Imagem Landsat mostrando a estrutura circular do Complexo Aimorés. 


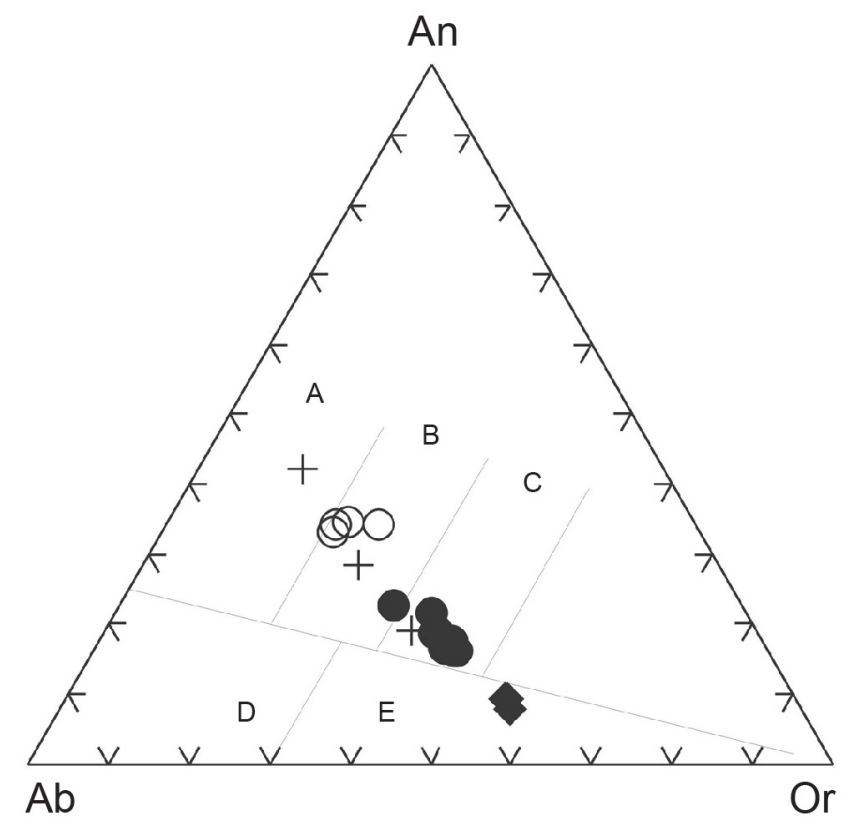

Figura 3. Diagrama de classificação de rochas ígneas ricas em quartzo proposto por O'Connor (1965). Campos: A. tonalitos; B. granodioritos; C. adamelito; D. trondhiemitos; E. granitos. Simbologia: $+=$ embasamento; $\mathbf{O}=$ hiperstênio monzodioritos; $\bullet$ = charnockitos; $\bullet$ granada-granitos.

truturas orientadas (Figura 5A), definidas pela orientação de enclaves ou schlierens e pelo alinhamento magmático de cristais. Os minerais essenciais são plagioclásio, piroxênios (clino e ortopiroxênio) e anfibólio, podendo incluir ainda quartzo e titanita. Como acessórios ocorrem apatita (o mais abundante), em geral inclusa no piroxênio, plagioclásio e anfibólio (Figura 4B), zircão e minerais opacos (magnetita/ilmenita). O piroxênio (entre 0,25 e 2,5 mm) é subidiomórfico e predomina ortopiroxênio (opx) em relação ao clinopiroxênio (cpx). O ortopiroxênio tem pleocroísmo verde a rosa-salmão, estrutura esquelética, e é substituído por anfibólio e/ou biotita ao longo de fraturas e clivagens ou ao redor dos grãos. Ocorre como agregados contendo inclusões de minerais opacos, apatita e zircão. O clinopiroxênio é augita e possui composição mais próxima a do diopsídio. O plagioclásio (entre 0,25 e $10 \mathrm{~mm}$ ) ocorre como megacristal e como integrante da matriz. Os cristais são idiomórficos (sobretudo os megacristais) a xenomórficos. Análises por intermédio de Microssonda Eletrônica forneceu composição andesina (cristais da matriz com $\mathrm{An}_{34,6-40,7}$ e os megacristais com $\mathrm{An}_{36,9-43,5}$ ) e, raramente, labradorita. O anfibólio (entre 0,5 e 2,5 mm) é uma hornblenda pargasítica e ocorre em cristais isolados ou na matriz associados aos minerais opacos (Figura 4B). A biotita (até $2 \mathrm{~mm}$ ), idiomórfica a subidiomórfica, é de cor castanha e associa-se ao anfibólio. A apatita (até $2,5 \mathrm{~mm}$ ) é o acessório mais abundante da rocha (até cerca de 3\%) (Tabela 1), enquanto zircão e magnetita/ilmenita ocorrem em menor quantidade. A Tabela 1 mostra as estimativas modais e normativas das unidades estudadas.

Charnockitos: são rochas porfiríticas contendo hyperstênio: uma delas de composição charnockítica e outra, mangerítica. No diagrama de classificação de rochas ígneas de O'Connor (1965), estas rochas situam-se no campo dos adamelitos, com uma das amostras situando-se no campo dos granodioritos (Figura 3). Mostram foliação magmática definida principalmente pela orientação de cristais de feldspatos e máficos (piroxênio e anfibólio). Esta estrutura é salientada pela presença de enclaves máficos, que conferem à rocha uma estrutura acamadada e são comuns feições de misturas de magmas (Figuras 5A e 5C). Os minerais essenciais são feldspato potássico, plagioclásio, quartzo, biotita, anfibólio e piroxênio (Figuras 4C e 4D). Os acessórios são apatita (mais abundante), zircão, allanita e minerais opacos (magnetita e ilmenita), ocorrendo ainda calcita e clorita como minerais de alteração, e pirita e esfalerita como provável fase de origem hidrotermal. O feldspato potássico (ortoclásio) e o plagioclásio são xenomórficos a subidiomórficos e ocorrem na matriz ou como megacristal (até $6 \mathrm{~cm}$ ). $\mathrm{O}$ feldspato de potássio é pertítico, zonado (contínuo ou oscilatório), e engloba o plagioclásio. Análises por microssonda eletrônica deste último forneceu composição oligoclásio-andesina. Os cristais maiores, zonados, apresentam inclusões de piroxênio, apatita, zircão e minerais opacos. São comuns feições deformacionais como lamelas recurvadas e fraturamento de grãos. O clinopiroxênio (entre 0,25 e $2 \mathrm{~mm}$ ), associado ao ortopiroxênio, é augita e situa-se mais próximo da composição da hedenbergita (diagrama não apresentado), sendo substituído na borda por anfibólio e/ou biotita. O forte pleocroísmo verde-rosa do ortopiroxênio caracteriza-o como hiperstênio, e a sua composição química situa-se no campo da ferrossilita (diagrama não aqui apresentado). O quartzo (até $1 \mathrm{~mm}$ ), com extinção ondulante incipiente, apresenta aspecto vermiforme e intercrescimento com plagioclásio sódico, formando mirmequitas. O anfibólio $(0,25$ e $1 \mathrm{~mm})$ é hornblenda ferro-pargasítica e contorna muitas vezes o ortopiroxênio. A biotita (até $1,5 \mathrm{~mm}$ ), castanha, é idiomórfica a subidiomórfica, substitui o anfibólio e mostra-se orientada nos domínios deformados. A apatita é idiomórfica (até 2,5 mm), a allanita, com halos pleocroicos característicos, mostra alto conteúdo em terras raras. A sequência de cristalização dos minerais inclui zircão, apatita, piroxênio, plagioclásio cálcico e anfibólio, como as fases precoces, e ilmenita, magnetita, biotita, ortoclásio e quartzo, como as fases tardias. 

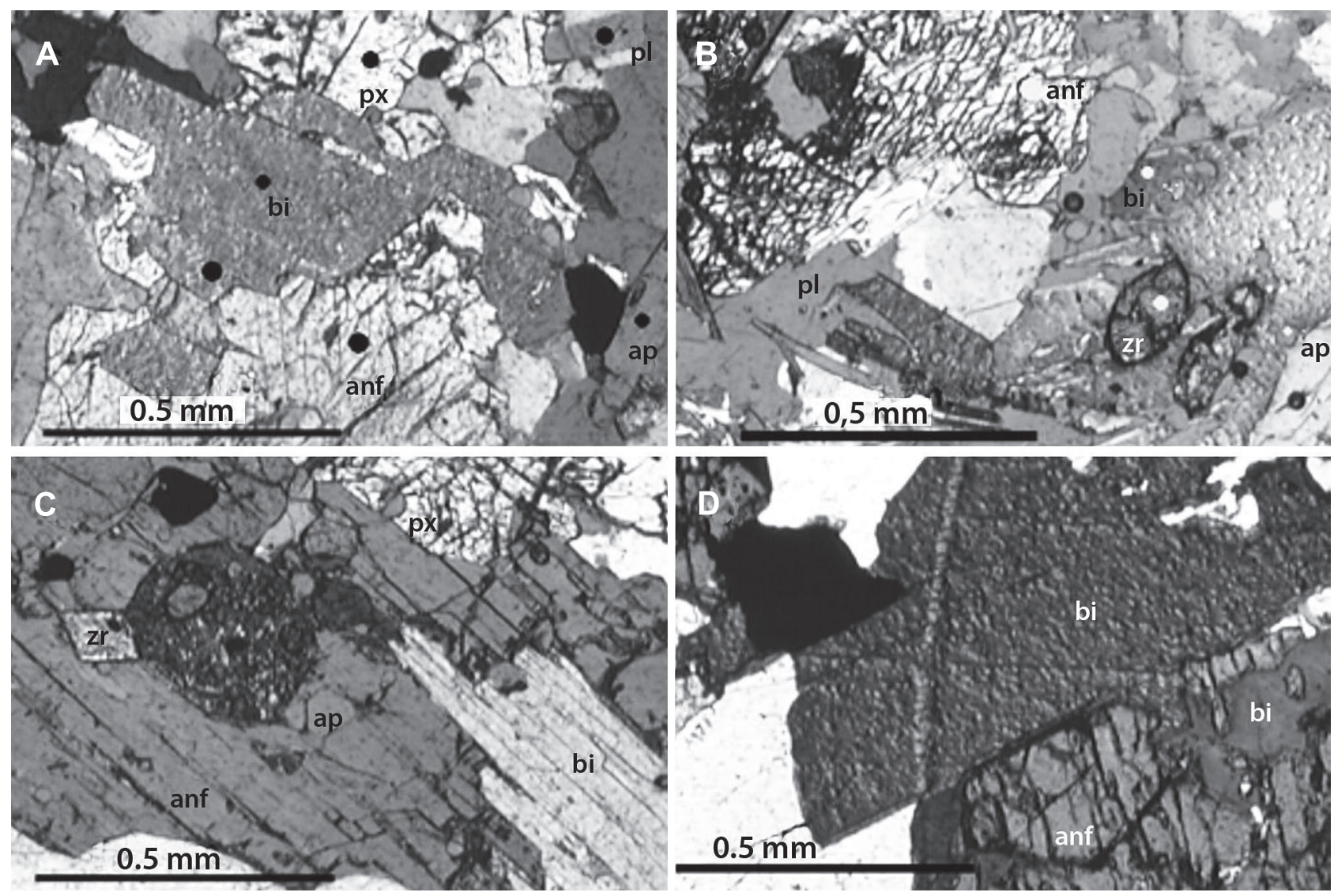

Figura 4. Fotomicrografias (nicóis cruzados) das unidades do Complexo Aimorés: A. amostra de monzodiorito (FAM 28) contendo piroxênio (px), anfibólio (anf) e biotita (bi); B. idem hy-monzodiorito (FAM 47) contendo anfibólio (canto superior esquerdo) e inclusões abundante de apatita em plagioclásio (pl); C. amostra de Charnockito (FAM 4) com grande cristal de anfibólio (anf) em contato com biotita (bi) contendo inclusão arredondada (escura) de piroxênio alterado e de cristais de zircão (zi) e apatita (ap); D. idem Charnockito (FAM 5) com grande cristal de biotita com traços de clivagem E-W em contato retilíneo com anfibólio (anf).

Granodioritos Porfiriticos: formam as elevações mais altas do maciço e ocorrem circundando os charnockitos com um formato circular. São constituídos por feldspato potássico + anfibólio + biotita + ilmenita/magnetita. Diferenciam-se dos charnockitos por não conter piroxênio na sua mineralogia. Apresentam estrutura maciça, homogênea, e textura porfirítica (Figura 5B) realçada pela alteração intempérica. A matriz é de granulação grossa a média/ fina, esta última nas porções deformadas.

Granada-Granitos: são rochas de cor branca-acinzentada a amarelada, quando alteradas. No diagrama de classificação de rochas ígneas de O'Connor (1965), estas rochas situam-se no campo dos granitos (Figura 3). Possuem contatos claramente intrusivos com os hy-monzodioritos (Figura 5D) e formam elevações que se destacam na paisagem. A granulação é grossa a média/fina, nos domínios deformados, e textura equigranular. Os mi- nerais essenciais são feldspato potássico, plagioclásio e quartzo. Granada, biotita, zircão, magnetita e ilmenita compõem os minerais acessórios. Feldspato potássico (microclínio) e plagioclásio são xenomórficos a subidiomórficos e ocorrem como megacristais e na matriz. $\mathrm{O}$ plagioclásio é de composição oligoclásio $\left(\mathrm{An}_{22,4-24,4}\right)$. A granada $(\sim 0,7 \mathrm{~mm})$ possui composição almandina-magnesiana. A biotita (até 1,0 mm), castanha, é idiomórfica a subidiomórfica.

Enclaves: na unidade de granada-granitos são encontrados enclaves de rochas básica a ácida, incluindo desde enclaves arredondados, que sugerem acentuado grau de assimilação, até enclaves com contatos angulosos, que evidenciam pouco ou nenhum grau de assimilação. Ocorrem dois tipos composicionais de enclaves: dioríticos e granodioríticos. Ocorrem também diques graníticos. $\mathrm{Na}$ parte central do complexo ocorre um corpo de pegmatito 

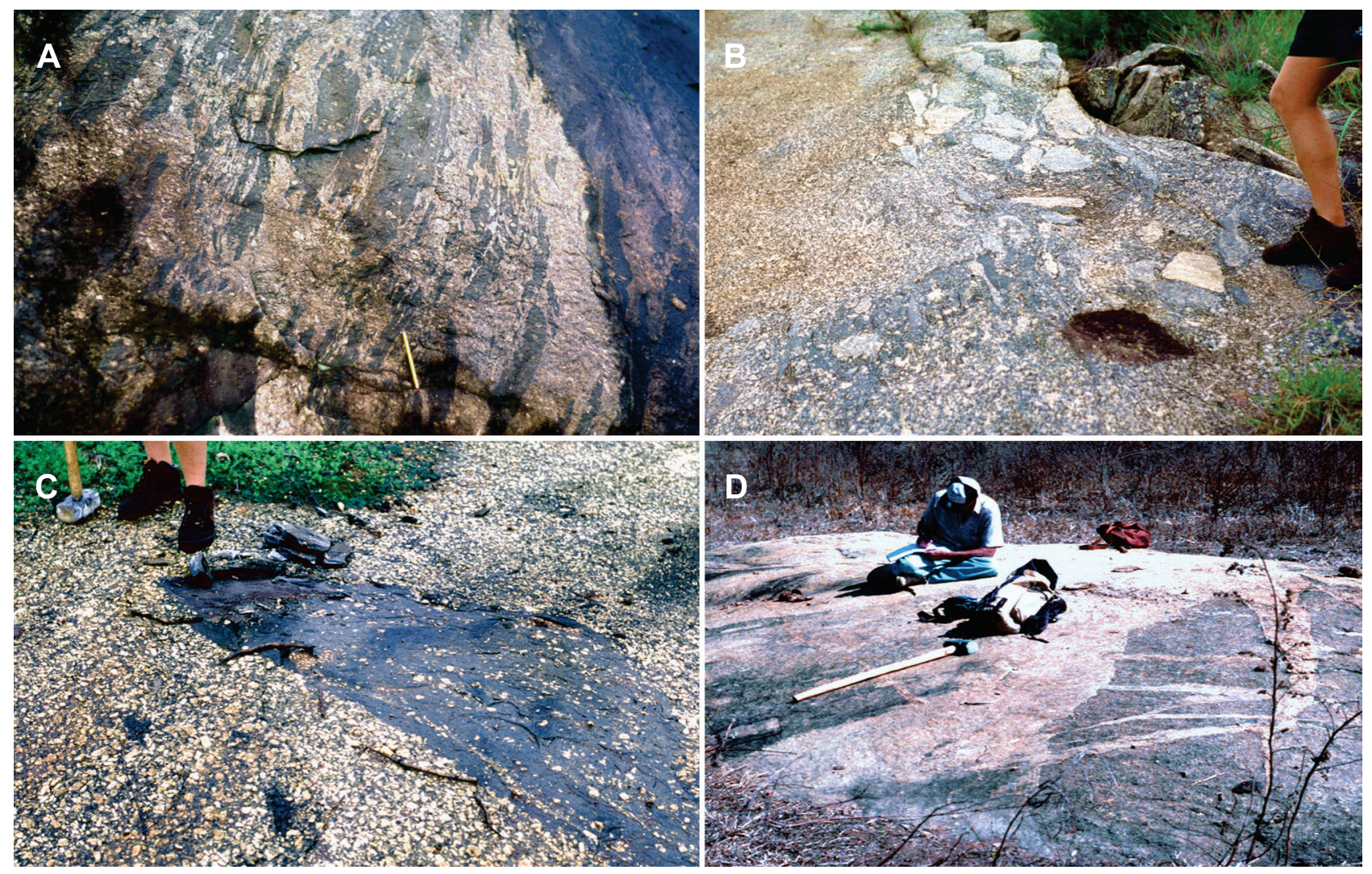

Figura 5. Fotografias das unidades do Complexo Aimorés. A. Porções máficas e félsicas (charnockito) orientados, com estrutura orientada, observadas próximo ao contato com a encaixante. B. Granodiorito porfirítico com estrutura magmática orientada e enclaves angulosos. C. Enclave básico com xenocristais (mega) de feldspato alcalino circundado por charnockito porfirítico em contato lobado e interpenetrativo, sugerindo mistura de magmas. D. Leucogranitos e pegmatitos cortando granodioritos.

com cerca de $50 \mathrm{~m}^{2}$ de exposição, constituído de quartzo, feldspato potássico e turmalina (abundante).

\section{Técnicas analíticas utilizadas}

As determinações de elementos maiores e traço foram feitas por duas técnicas espectrométricas: por fluorescência de raios-X e espectrometria de emissão por ICP (Induced Coupled Plasma). Tais determinações foram efetuadas na Escola de Minas de Saint-Etienne, na França. No primeiro caso utilizou-se um espectrômetro marca Philips, modelo PW 1404, enquanto no segundo empregou-se um espectrômetro modelo JY38PI + JY32P. Os limites de detecção da fluorescência de raios-X para os elementos traço analisados foram os seguintes: $\mathrm{Sr}, \mathrm{Y}, \mathrm{Zr}$ e $\mathrm{Nb}-1,5 \mathrm{ppm}$; $\mathrm{Ni}$, $\mathrm{Cu}, \mathrm{Zn}, \mathrm{Ga}$ e Rb - 2 ppm; Hf, W, Pb, Sn, Th e U - 3 ppm; $\mathrm{Ba}-3,5$ ppm; Cs - 5 ppm; La - 7,5 ppm e Ce - 8 ppm. Com relação aos elementos maiores, expressos sob a forma de óxidos, o limite de detecção do equipamento é $0,01 \%$. As análises quantitativas dos elementos constituintes das fases minerais foram efetuadas em Microssonda Eletrônica marca Camebax SX-100 e SX-50, a primeira do Departamento de Ciências da Terra da Universidade Blaise-Pascal, Clermont-Ferrand, França, e a segunda da Universidade de Paris-VI (Jussieu), em Paris. Em ambos os casos, as condições do equipamento para análise foram as seguintes: tensão de aceleração $=15 \mathrm{KV}$; intensidade de corrente $=15 \mathrm{nA}$; superfície utilizada para análise $=1 \mu \mathrm{m}^{2}$ e tempo de contagem $=20 \mathrm{~s}$. Maiores detalhes sobre o procedimento analítico pode ser visto em Mello (2000). Para os estudos geoquímicos (elementos maiores, menores e traço) foram selecionadas 26 amostras representativas das unidades do Complexo Aimorés, bem como de amostras de enclaves e das rochas encaixantes, cujos resultados se acham re- 


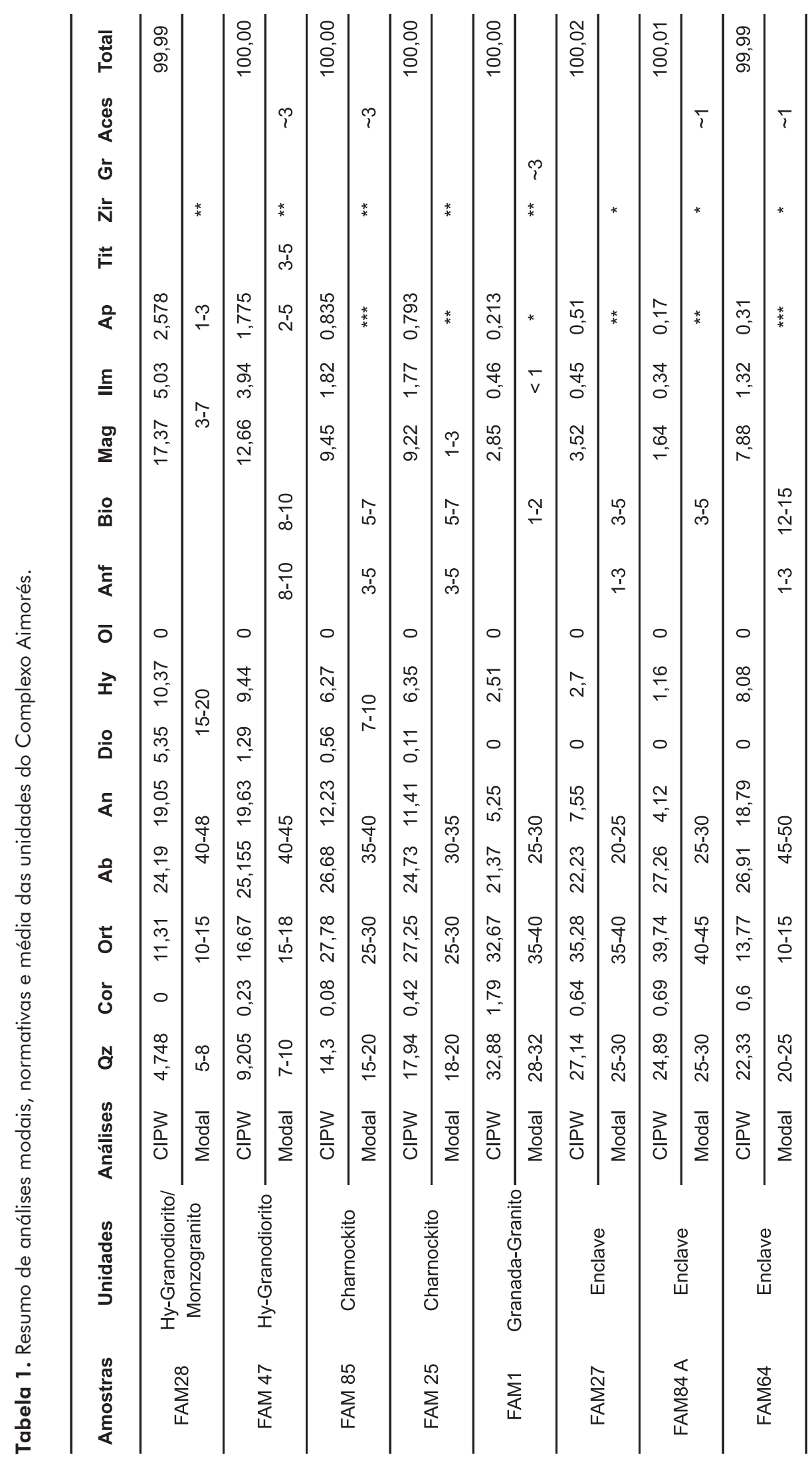


lacionados na Tabela 2. Foram também realizadas análises modais de amostras consideradas representativas das diferentes unidades e fácies que compõem o referido complexo (ver Tabela 1). As denominações para as rochas estudadas foram baseadas no diagrama de Middlemost (1994) e encontram-se designadas na Tabela 2.

\section{Caracterização Geoquímica}

O conteúdo em $\mathrm{Si}_{2}$ das rochas do Complexo Aimorés varia de 50,73 a 74,65\%, com os monzodioritos apresentando entre 50,73 e $55,78 \%$, os charnockitos, entre 60,69 e $67,43 \%$, e os granada-granitos, entre 72,76 e $74,65 \%$ (Tabela 2). Os enclaves apresentam valores entre 65,43 e $72,27 \%$, e as encaixantes, entre 54,93 e 73,5\% (ver Tabela 2). Os monzodioritos diferenciam-se das demais unidades do complexo pelos conteúdos mais elevados em $\mathrm{TiO}_{2}(2,33$ - 2,94\%) e $\operatorname{Mg} 0\left(2,3\right.$ - 3,51\%), porém mais baixos em $\mathrm{K}_{2} 0$ (2,19 - 2,84\%). O conteúdo em Ba (1.508 - 1.816 ppm) é semelhante ao dos charnockitos (1.352 - 1.842 ppm). Os leucogranitos com granada, com exceção dos enclaves, são mais enriquecidos em $\mathrm{K}_{2} 0(5,34-5,90 \%)$, porém mais empobrecidos em $\mathrm{TiO}_{2}(0,24$ - 0,28\%), $\operatorname{Mg} 0(0,47$ - 0,53\%) e $\mathrm{Zr}(108$ - $135 \mathrm{ppm})$. Duas amostras de enclave (EF27 e EF84) apresentam os conteúdos mais elevados em $\mathrm{K}_{2} 0$ $(6,11-6,77 \%)$ e contrastam com uma amostra da encaixante (BF 86A), que é mais baixa neste elemento $(3,93 \%)$, com teor similar em $\mathrm{SiO}_{2}(73,50 \%)$.

No diagrama de saturação em alumina (Figura 5A), os monzodioritos e charnockitos situam-se no campo metaluminoso ( $\mathrm{A} / \mathrm{CNK} \leq 1)$, enquanto os leucogranitos mostram-se peraluminosos (A/CNK, entre 1,1 e 1,16). Os enclaves e duas amostras da encaixante (BF 80, BF 86) são marginalmente peraluminosos (A/CNK, entre 1,0 e 1,1) (Figura 6).

No diagrama de classificação das séries magmáticas de Irvine e Baragar (1971), grande parte das amostras analisadas situa-se no campo da série subalcalina, com exceção dos monzodioritos que se situam no campo da série alcalina (Figura 6B). Os enclaves e as encaixantes são subalcalinos.

Nos diagramas de Harker fica evidenciado para as amostras do Complexo Aimorés uma forte correlação negativa para alguns elementos como $\mathrm{Ca}, \mathrm{Mg}, \mathrm{Fe}, \mathrm{P}$ e Ti, sendo menos acentuada para o $\mathrm{Sr}, \mathrm{Na}$ e $\mathrm{Y}$, com correlação positiva para $\mathrm{K}, \mathrm{Rb}$ e $\mathrm{Th}$, apesar de uma certa dispersão das amostras (Figuras 7A, 7B e 7C). O Al cresce com a diferenciação nos hy-monzodioritos e decresce nos charnockitos e granada-granitos, enquanto o $\mathrm{Ba}$ apresenta comportamento inverso (Figuras 7A, 7B e 7C). Os diagramas com $\mathrm{Zr}$, Nb e Y, embora mostrem correlação negativa com a sílica, apresentam alinhamentos com gradientes diferentes para cada uma das unidades estudadas, sugerindo tratar-se de séries desvinculadas geneticamente (Figuras 7A, 7B e 7C). Duas amostras de enclave granítico (EF 27, EF 84) apresentam boa correlação nos diferentes diagramas confeccionados, acompanhando em geral a tendência dos leucogranitos. Um enclave (GF 9) de composição intermediária $(65,43 \%)$ não segue o mesmo comportamento.

As amostras das encaixantes, embora se apresentem alinhadas em alguns dos diagramas de Harker, são mais enriquecidas em $\mathrm{Ca}, \mathrm{Mg}$, relativamente em $\mathrm{Na}$, e mais empobrecidas em K, Rb, Ba, Nb, Y e Zr (Figuras 7A, 7B e 7C).

Os diagramas de elementos incompatíveis ( $\mathrm{Rb}, \mathrm{Zr}$ e $\mathrm{Sr}$ ) vs. compatíveis $(\mathrm{V}, \mathrm{Mg}$ e $\mathrm{Ti})$ mostram correlações positivas em alguns diagramas (Figuras 8A e 8C) e negativas em

A
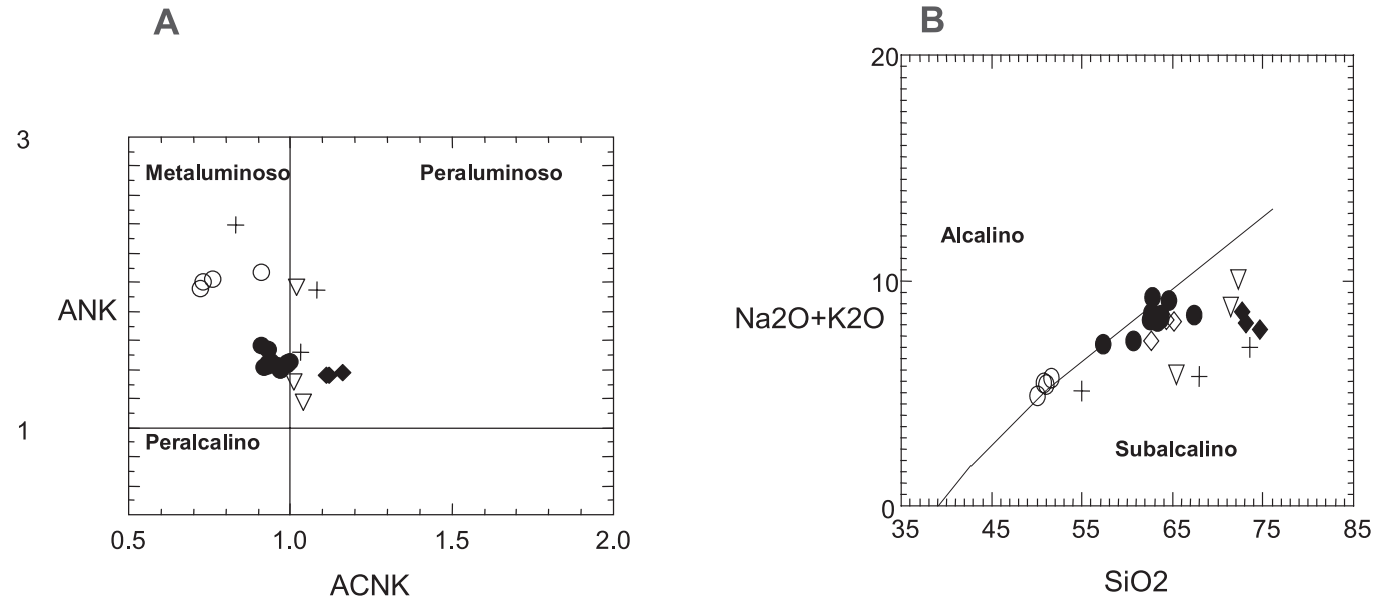

Figura 6. Diagramas: A. saturação em alumina (A/CNK vs. A/NK) de Maniar e Piccoli (1989); B. classificação de séries magmáticas de Irvine e Baragar (1971), mostrando a distribuição das rochas do Complexo Aimorés, do embasamento e enclaves. 
Tabela 2. Análises químicas de elementos maiores, menores (\% em peso) e traço (em ppm) e parâmetros geoquímicos para as rochas do Complexo Aimorés e Embasamento. Legenda: n.d. = não detectado; P.F. = Perda ao fogo; $\mathbf{A} / \mathbf{C N K}=\mathrm{Al} 2 \mathrm{O} 3 /(\mathrm{N} 2 \mathrm{O}+\mathrm{CaO}+\mathrm{K} 2 \mathrm{O}) ; \mathbf{M g} \#=(\mathrm{MgO} / 40,3) /\{(\mathrm{MgO} / 40,3)+(\mathrm{Fe} 2 \mathrm{O} 3 / 159,69) * 2\}$; Eu/Eu*N = (Eu/0,0735)/\{[(Sm/0,195) +(Gd/0,259)]/2\}. Normalização utilizada: Boynton, 1984.

\begin{tabular}{|c|c|c|c|c|c|c|c|c|c|c|c|}
\hline \multirow{2}{*}{$\begin{array}{l}\text { Unidade } \\
\text { Amostra }\end{array}$} & \multicolumn{4}{|c|}{ Hiperstênio Monzodioritos } & \multicolumn{7}{|c|}{ Charnockitos } \\
\hline & AM28 & AM52 & AM85 & AM47 & AM84D & AM84E & AM4L & AM84F & AM4 & AM4J & AM4K \\
\hline $\mathrm{SiO} 2$ & 50,73 & 51 & 51,62 & 55,78 & 60,69 & 62,57 & 62,6 & 62,71 & 62,84 & 63,35 & 63,78 \\
\hline $\mathrm{TiO} 2$ & 2,92 & 2,94 & 2,66 & 2,33 & 1,4 & 1,14 & 1,1 & 1,03 & 0,76 & 0,9 & 0,94 \\
\hline $\mathrm{Al} 2 \mathrm{O} 3$ & 15,19 & 15,35 & 16,05 & 16,41 & 15,39 & 15,62 & 15,5 & 15,98 & 16,75 & 15,37 & 15,89 \\
\hline $\mathrm{Fe} 2 \mathrm{O} 3$ & 13,65 & 13,7 & 12,71 & 9,68 & 9,73 & 7,74 & 7,34 & 7,14 & 5,33 & 6 & 6,24 \\
\hline $\mathrm{MnO}$ & 0,2 & 0,2 & 0,19 & 0,14 & 0,16 & 0,13 & 0,12 & 0,11 & 0,09 & 0,1 & 0,1 \\
\hline $\mathrm{MgO}$ & 3,46 & 3,51 & 2,88 & 2,3 & 1,39 & 1,14 & 1,09 & 1 & 0,83 & 0,93 & 0,88 \\
\hline Cão & 7,37 & 7,41 & 7,29 & 5,5 & 3,93 & 3,32 & 3,23 & 3,32 & 2,86 & 2,71 & 3,33 \\
\hline $\mathrm{Na} 2 \mathrm{O}$ & 3,27 & 3,22 & 3,23 & 2,96 & 3,43 & 3,34 & 3,4 & 3,56 & 3,48 & 3,2 & 3,35 \\
\hline $\mathrm{K} 2 \mathrm{O}$ & 2,2 & 2,19 & 2,43 & 2,84 & 3,88 & 4,89 & 4,86 & 4,98 & 5,79 & 4,98 & 4,98 \\
\hline $\mathrm{P} 2 \mathrm{O} 5$ & 1,38 & 1,4 & 1,24 & 0,95 & 0,57 & 0,42 & 0,42 & 0,4 & 0,3 & 0,34 & 0,38 \\
\hline P.F. & 0 & 0 & 0,21 & 0,59 & 0,18 & 0,27 & 0,41 & 0,16 & 0,63 & 0,46 & 0,61 \\
\hline Total & 100,36 & 100,91 & 100,51 & 99,48 & 100,74 & 100,57 & 100,08 & 100,41 & 99,65 & 98,34 & 100,48 \\
\hline $\mathrm{Ba}$ & 1816,9 & 1580,3 & 1659,5 & 1508,6 & 1325,4 & 1725,5 & 1645,1 & 1755,6 & 1842,1 & 1745,6 & 1688,9 \\
\hline $\mathrm{Rb}$ & 42,7 & 32,4 & 37,1 & 80,5 & 120,5 & 146,6 & 124,5 & 130,1 & 138,6 & 137,3 & 125,4 \\
\hline $\mathrm{Sr}$ & 529,6 & 578,5 & 650,7 & 488,2 & 291,9 & 307 & 302,7 & 322 & 318,3 & 292,4 & 298,7 \\
\hline $\mathrm{Ga}$ & 25 & 25,4 & 26,6 & 22,7 & 24,3 & 23,3 & 23,8 & 24,1 & 24,1 & 22,5 & 23,2 \\
\hline $\mathrm{Nb}$ & 51,8 & 44,9 & 43,6 & 36,3 & 45,4 & 47 & 29,8 & 37,3 & 44,9 & 33,8 & 29 \\
\hline $\mathrm{Hf}$ & 13,5 & 11 & 12,7 & 11,2 & 12,8 & 14,9 & 13,6 & 13,1 & 10,6 & 15,5 & 14 \\
\hline $\mathrm{Zr}$ & 556,6 & 496,7 & 469,2 & 431,8 & 614,4 & 560 & 566,8 & 520,5 & 435,6 & 480,7 & 469 \\
\hline$Y$ & 50,8 & 46,8 & 47,8 & 40,8 & 44,4 & 37,4 & 33,5 & 28,7 & 22,8 & 27,8 & 21,7 \\
\hline Th & 2,2 & 2,9 & 6,4 & 3,7 & 6,5 & 12 & 5,5 & 7,7 & 8,2 & 9,5 & 8,5 \\
\hline $\mathrm{Cr}$ & 1,44 & 1,17 & 3,95 & 5,12 & 2,41 & 3,08 & 3,03 & 2,7 & 3,3 & 2,75 & 2,49 \\
\hline $\mathrm{Ni}$ & 4,49 & 4,16 & 5,01 & 5,25 & 2,61 & 2,56 & 2,18 & 1,79 & 1,94 & 1,88 & 1,94 \\
\hline $\mathrm{Sc}$ & 21,8 & 24,1 & 19,4 & 18,2 & 19 & 14 & 12,1 & 11,8 & 9,24 & 10,3 & 8,89 \\
\hline $\mathrm{V}$ & 166 & 171 & 142 & 136 & 54,7 & 39,3 & 39,2 & 31,7 & 29,5 & 31,7 & 29 \\
\hline $\mathrm{Pb}$ & 15,4 & 12,2 & 14,6 & 17 & 18,1 & 19,9 & 22,3 & 22,8 & 22,9 & 22,2 & 23,8 \\
\hline $\mathrm{Zn}$ & 128,3 & 136,3 & 124,5 & 123,3 & 135,3 & 109,7 & 106,6 & 93 & 83,4 & 98,8 & 93 \\
\hline W & 70,8 & 55,4 & 16,1 & 129,7 & 16,7 & 14,8 & 18,5 & 26,8 & 346,7 & 18,1 & 20,8 \\
\hline ACNK & 0,72 & 0,73 & 0,76 & 0,91 & 0,91 & 0,93 & 0,93 & 0,92 & 0,97 & 0,99 & 0,94 \\
\hline $\mathrm{Mg} \#$ & 0,33 & 0,34 & 0,31 & 0,32 & 0,22 & 0,23 & 0,23 & 0,22 & 0,24 & 0,23 & 0,22 \\
\hline $\mathrm{K} / \mathrm{Rb}$ & 428 & 561 & 544 & 293 & 267 & 277 & 324 & 318 & 347 & 301 & 330 \\
\hline $\mathrm{Rb} / \mathrm{Sr}$ & 0,08 & 0,06 & 0,06 & 0,16 & 0,41 & 0,48 & 0,41 & 0,4 & 0,44 & 0,47 & 0,42 \\
\hline La & 86 & 75,6 & 72,1 & 86,4 & 66,1 & 68,8 & 62,8 & 54,8 & 64,2 & 65,8 & 51,4 \\
\hline $\mathrm{Ce}$ & 196 & 172 & 154 & 196 & 161 & 169 & 143 & 111 & 136 & 139 & 111 \\
\hline $\mathrm{Nd}$ & 98,4 & 108 & 98,4 & 100 & 0 & 0 & 72,4 & 61,3 & n.d. & n.d. & n.d. \\
\hline $\mathrm{Sm}$ & 20,5 & 19,5 & 16,4 & 19,7 & 0 & 0 & 15,9 & 13,6 & n.d. & n.d. & n.d. \\
\hline $\mathrm{Eu}$ & 4,17 & 3,99 & 4,05 & 3,18 & 3,15 & 3,29 & 2,71 & 2,38 & 3,31 & 3,16 & 2,8 \\
\hline $\mathrm{Gd}$ & 13,4 & 12,9 & 12,4 & 11,4 & n.d. & n.d. & 9,67 & 8,22 & n.d. & n.d. & n.d. \\
\hline Dy & 9,62 & 9,52 & 9,47 & 7,96 & n.d. & n.d. & 6,82 & 5,7 & n.d. & n.d. & n.d. \\
\hline $\mathrm{Er}$ & 4,52 & 4,77 & 4,41 & 3,6 & n.d. & n.d. & 3,08 & 2,57 & n.d. & n.d. & n.d. \\
\hline $\mathrm{Yb}$ & 3,53 & 3,3 & 3,43 & 2,58 & 4,17 & 3,27 & 2,34 & 1,91 & 2,06 & - & - \\
\hline TotalETR & 436,14 & 409,58 & 374,66 & 430,82 & - & - & 318,72 & 261,48 & - & - & - \\
\hline$(\mathrm{Ce} / \mathrm{Yb}) \mathrm{N}$ & 14,36 & 13,48 & 11,61 & 19,65 & 9,99 & 13,37 & 15,81 & 15,03 & 17,08 & 14,44 & 12,01 \\
\hline$(\mathrm{Dy} / \mathrm{Yb}) \mathrm{N}$ & 1,77 & 1,87 & 1,79 & 2 & - & - & 1,89 & 1,94 & - & - & - \\
\hline $\left.\mathrm{Eu} / \mathrm{Eu}^{*}\right) \mathbf{N}$ & 0,72 & 0,72 & 0,84 & 0,6 & - & - & 0,62 & 0,64 & - & - & - \\
\hline
\end{tabular}


Tabela 2. (continuação)

\begin{tabular}{|c|c|c|c|c|c|c|c|c|c|c|c|}
\hline \multirow{2}{*}{$\begin{array}{l}\text { Unidade } \\
\text { Amostra }\end{array}$} & \multicolumn{5}{|c|}{ Charnockitos } & \multicolumn{3}{|c|}{ Granada-Granitos } & \multicolumn{3}{|c|}{ Embasamento } \\
\hline & AM4H & AM84C & AM25 & AM24A & AM5A & AM9B & AM1 & AM9A & AM86B & AM80B & AM86A \\
\hline $\mathrm{SiO} 2$ & 63,8 & 67,43 & 62,59 & 64,27 & 65,11 & 72,76 & 73,08 & 74,65 & 54,93 & 67,92 & 73,5 \\
\hline $\mathrm{TiO} 2$ & 0,96 & 0,67 & 1,22 & 0,84 & 0,89 & 0,24 & 0,21 & 0,28 & 1,33 & 0,58 & 0,26 \\
\hline $\mathrm{Al} 2 \mathrm{O} 3$ & 15,64 & 15,42 & 14,82 & 15,27 & 15,43 & 14,81 & 14,11 & 13,36 & 18,03 & 15,48 & 14,09 \\
\hline $\mathrm{Fe} 2 \mathrm{O} 3$ & 6,27 & 4,67 & 8,55 & 5,68 & 5,91 & 1,76 & 1,81 & 2,44 & 9,42 & 4,59 & 2 \\
\hline $\mathrm{MnO}$ & 0,1 & 0,08 & 0,14 & 0,09 & 0,09 & 0,03 & 0,02 & 0,04 & 0,15 & 0,07 & 0,04 \\
\hline $\mathrm{MgO}$ & 0,95 & 0,71 & 1,24 & 0,96 & 0,98 & 0,5 & 0,47 & 0,53 & 2,97 & 1,49 & 0,35 \\
\hline $\mathrm{CaO}$ & 2,95 & 2,7 & 3,47 & 2,6 & 2,64 & 1,32 & 1,09 & 1,17 & 7,77 & 3,54 & 2,39 \\
\hline $\mathrm{Na} 2 \mathrm{O}$ & 3,23 & 3,32 & 3,02 & 3,1 & 3,12 & 2,74 & 2,52 & 2,45 & 3,6 & 3,08 & 3,07 \\
\hline $\mathrm{K} 2 \mathrm{O}$ & 5,24 & 5,13 & 4,32 & 5,12 & 5,09 & 5,9 & 5,6 & 5,34 & 1,5 & 2,66 & 3,93 \\
\hline P2O5 & 0,38 & 0,31 & 0,47 & 0,34 & 0,34 & 0,08 & 0,13 & 0,09 & 0,37 & 0,17 & 0,05 \\
\hline P.F. & 0,46 & 0,41 & 0,38 & 0,38 & 0,36 & 0,41 & 0,4 & 0,44 & 0,61 & 0,5 & 0,35 \\
\hline Total & 100 & 100,85 & 100,23 & 98,66 & 99,96 & 100,56 & 99,45 & 100,8 & 100,69 & 100,08 & 100,04 \\
\hline $\mathrm{Ba}$ & 1740,8 & 1784,1 & 1752,6 & 1413,3 & 1489,1 & 560,1 & 370,8 & 379,5 & 812,7 & 575,5 & 1536,4 \\
\hline $\mathrm{Rb}$ & 129,5 & 134,2 & 124,5 & 160,5 & 227,1 & 152,9 & 144,6 & 138,7 & 39,6 & 95,2 & 74,6 \\
\hline $\mathrm{Sr}$ & 295,5 & 304,3 & 314,9 & 249,1 & 250,6 & 109,4 & 75,1 & 77,5 & 451,3 & 176 & 268,5 \\
\hline $\mathrm{Ga}$ & 22,1 & 21,1 & 22,4 & 22,8 & 24,8 & 17,1 & 15,2 & 16,2 & 20,6 & 18,8 & 13,5 \\
\hline $\mathrm{Nb}$ & 33,7 & 23,6 & 52,2 & 32,8 & 36,3 & 10,2 & 7,96 & 12,9 & 15,3 & 10,5 & 6,07 \\
\hline $\mathrm{Hf}$ & 13,4 & 10,8 & 10,7 & 10,6 & 8,4 & 3,6 & 3 & 3 & 5,9 & 4,5 & 5 \\
\hline $\mathrm{Zr}$ & 513,5 & 352,5 & 593,2 & 451,2 & 480,7 & 135,6 & 108,2 & 115,2 & 225,4 & 188,1 & 98,8 \\
\hline$Y$ & 26,6 & 20,2 & 49,7 & 31,3 & 34,2 & 29 & 8,69 & 23,2 & 34,4 & 9,18 & 6,26 \\
\hline Th & 4,4 & 5,2 & 10 & 12,3 & 12,4 & 27,6 & 14 & 24,3 & 2,4 & 7,7 & 7,1 \\
\hline $\mathrm{Cr}$ & 2,87 & 2,51 & 2,56 & 2,37 & 2,27 & 4,37 & 3,69 & 4,21 & 25 & 16,3 & 1,67 \\
\hline $\mathrm{Ni}$ & 1,79 & 1,64 & 1,91 & 1,05 & 1,56 & 1,73 & 1,11 & 1,71 & 7,78 & 7,59 & 0,852 \\
\hline $\mathrm{Sc}$ & 11,6 & 5,96 & 16,8 & 7,35 & 9,23 & 3,31 & 2,14 & 4,01 & 27,2 & 9,91 & 2,99 \\
\hline $\mathrm{V}$ & 32,6 & 22,3 & 42,5 & 30,6 & 34,6 & 11,5 & 5,67 & 10,3 & 185 & 69 & 24,5 \\
\hline $\mathrm{Pb}$ & 22,9 & 23 & 22,1 & 24,2 & 24,6 & 44 & 34,4 & 36,7 & 3,6 & 9 & 15 \\
\hline $\mathrm{Zn}$ & 94,9 & 69 & 129,8 & 96,4 & 100,3 & 43 & 33,4 & 43,1 & 96,5 & 61,8 & 34,2 \\
\hline w & 20,7 & 20,8 & 124,3 & 74,1 & 84,3 & 164,9 & 295,8 & 205,3 & 20,4 & 16,9 & 20,5 \\
\hline ACNK & 0,96 & 0,97 & 0,93 & 0,99 & 1 & 1,11 & 1,16 & 1,12 & 0,83 & 1,08 & 1,03 \\
\hline $\mathrm{Mg \#}$ & 0,23 & 0,23 & 0,22 & 0,25 & 0,25 & 0,36 & 0,34 & 0,3 & 0,38 & 0,39 & 0,26 \\
\hline $\mathrm{K} / \mathrm{Rb}$ & 336 & 317 & 288 & 265 & 186 & 320 & 321 & 320 & 314 & 232 & 437 \\
\hline $\mathrm{Rb} / \mathrm{Sr}$ & 0,44 & 0,44 & 0,4 & 0,64 & 0,91 & 1,4 & 1,93 & 1,79 & 0,09 & 0,54 & 0,28 \\
\hline $\mathrm{La}$ & 50,3 & 48,8 & 47,8 & 82,7 & 95,3 & 55,2 & 20,1 & 42,7 & 25,2 & 37 & 20,7 \\
\hline $\mathrm{Ce}$ & 114 & 112 & 118 & 119 & 137 & 118 & 41,2 & 89,5 & 76,8 & 93,9 & 48,4 \\
\hline $\mathrm{Nd}$ & n.d. & n.d. & 82,2 & 80,5 & 91,1 & 63,5 & 21,5 & n.d. & n.d. & n.d. & n.d. \\
\hline $\mathrm{Sm}$ & n.d. & n.d. & 16,2 & 13,3 & 15,7 & 12,8 & 4,49 & n.d. & n.d. & n.d. & n.d. \\
\hline $\mathrm{Eu}$ & 3,24 & 2,59 & 3,37 & 2,17 & 2,54 & 0,763 & 0,494 & 0,65 & 2,09 & 1,34 & 1,08 \\
\hline $\mathrm{Gd}$ & n.d. & n.d. & 12,1 & 8,71 & 9,64 & 8,32 & 3,81 & n.d. & n.d. & n.d. & n.d. \\
\hline Dy & n.d. & n.d. & 9,34 & 6,11 & 7,44 & 5,11 & 2,11 & n.d. & n.d. & n.d. & n.d. \\
\hline $\mathrm{Er}$ & n.d. & n.d. & 4,61 & 2,85 & 3,35 & 3,09 & 0,645 & n.d. & n.d. & n.d. & n.d. \\
\hline $\mathrm{Yb}$ & 2,54 & 1,83 & 3,39 & 2,15 & 2,32 & 2,69 & 0,418 & 2,15 & 3,65 & 0,611 & 0,612 \\
\hline Total ETR & - & - & 297,01 & 317,49 & 364,39 & 269,473 & 94,767 & - & - & - & - \\
\hline$(\mathrm{Ce} / \mathrm{Yb}) \mathrm{N}$ & 11,61 & 15,83 & 9 & 14,32 & 15,27 & 11,35 & 25,5 & 10,77 & 5,44 & 39,75 & 20,46 \\
\hline (Dy/ Yb)N & - & - & 1,79 & 1,84 & 2,08 & 1,23 & 3,28 & - & - & - & - \\
\hline$\left(E u / E u^{*}\right) N$ & - & - & 0,71 & 0,58 & 0,59 & 0,21 & 0,36 & - & - & - & - \\
\hline
\end{tabular}



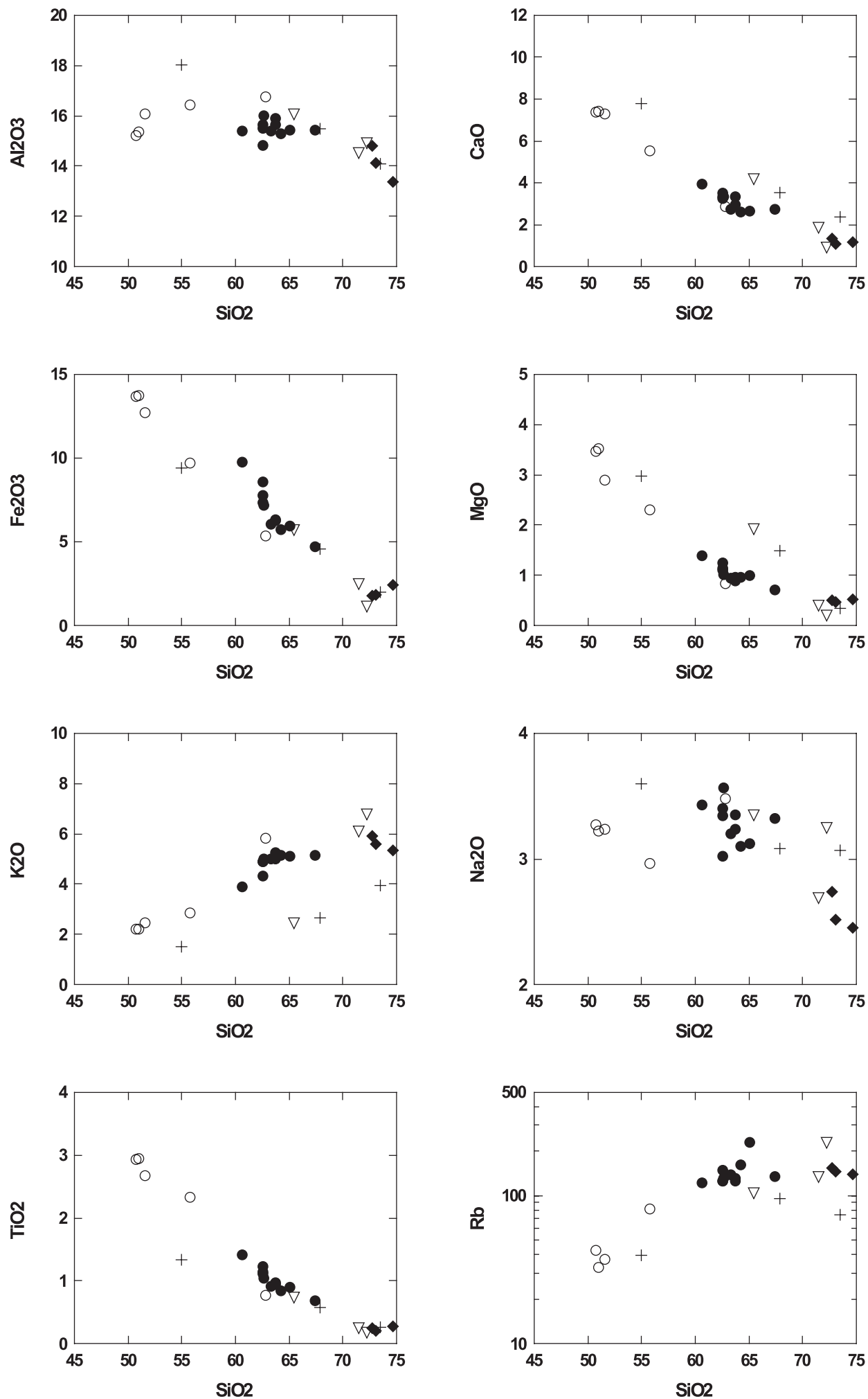

Figura 7A. Diagramas de Harker das rochas do Complexo Aimorés. Óxidos em \% em peso; outros elementos em ppm. Simbologia: $+=$ embasamento; 0 = hiperstênio monzodioritos; $\bullet=$ charnockitos; $\bullet$ granada-granitos; $\nabla=$ enclaves. 

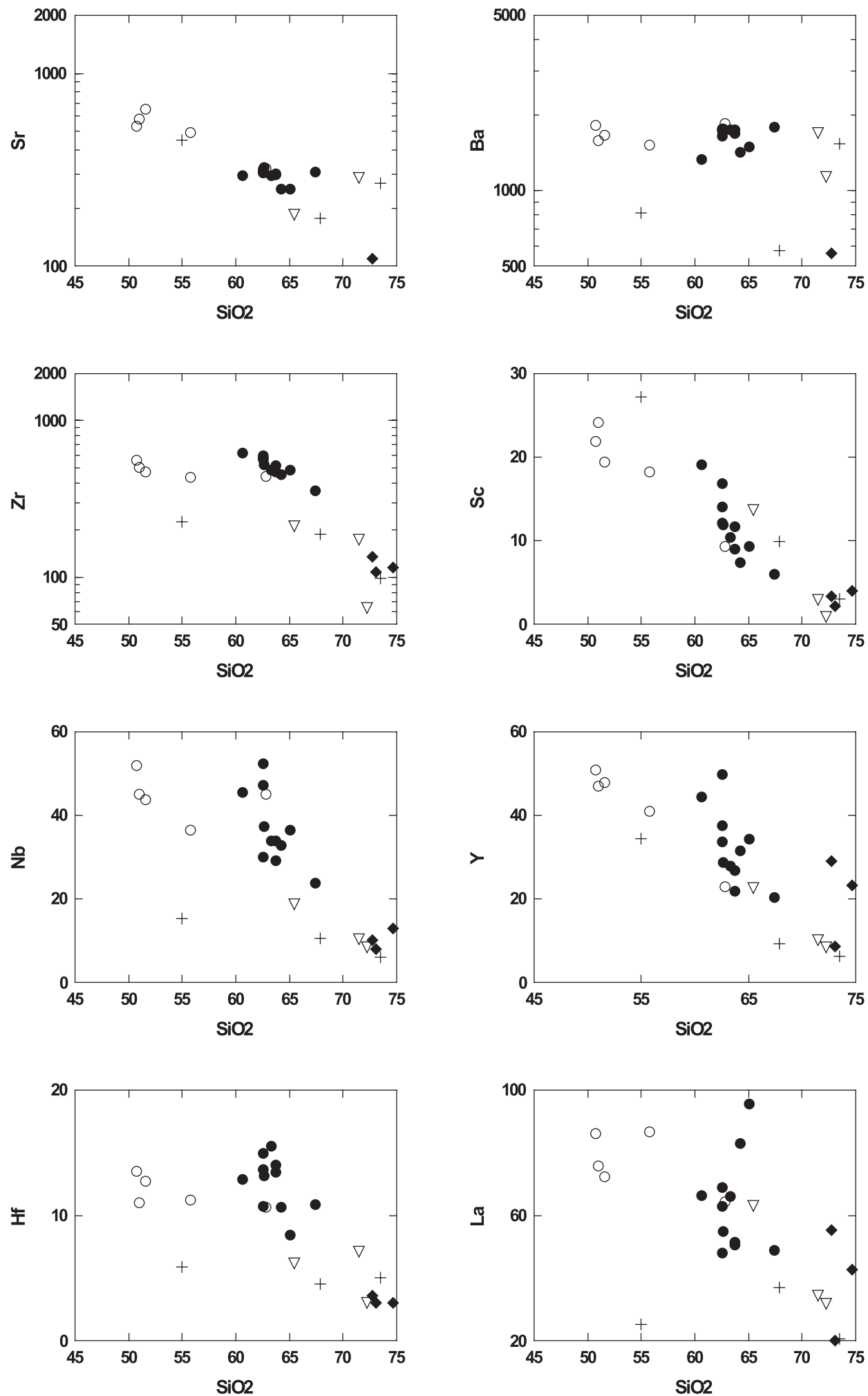

Figura 7B. Diagramas de Harker das rochas do Complexo Aimorés. Óxidos em \% em peso; outros elementos em ppm. Simbologia: $+=$ embasamento; $\mathbf{O}=$ hiperstênio monzodioritos; - = charnockitos; $\bullet$ granada-granitos; $\nabla=$ enclaves. 

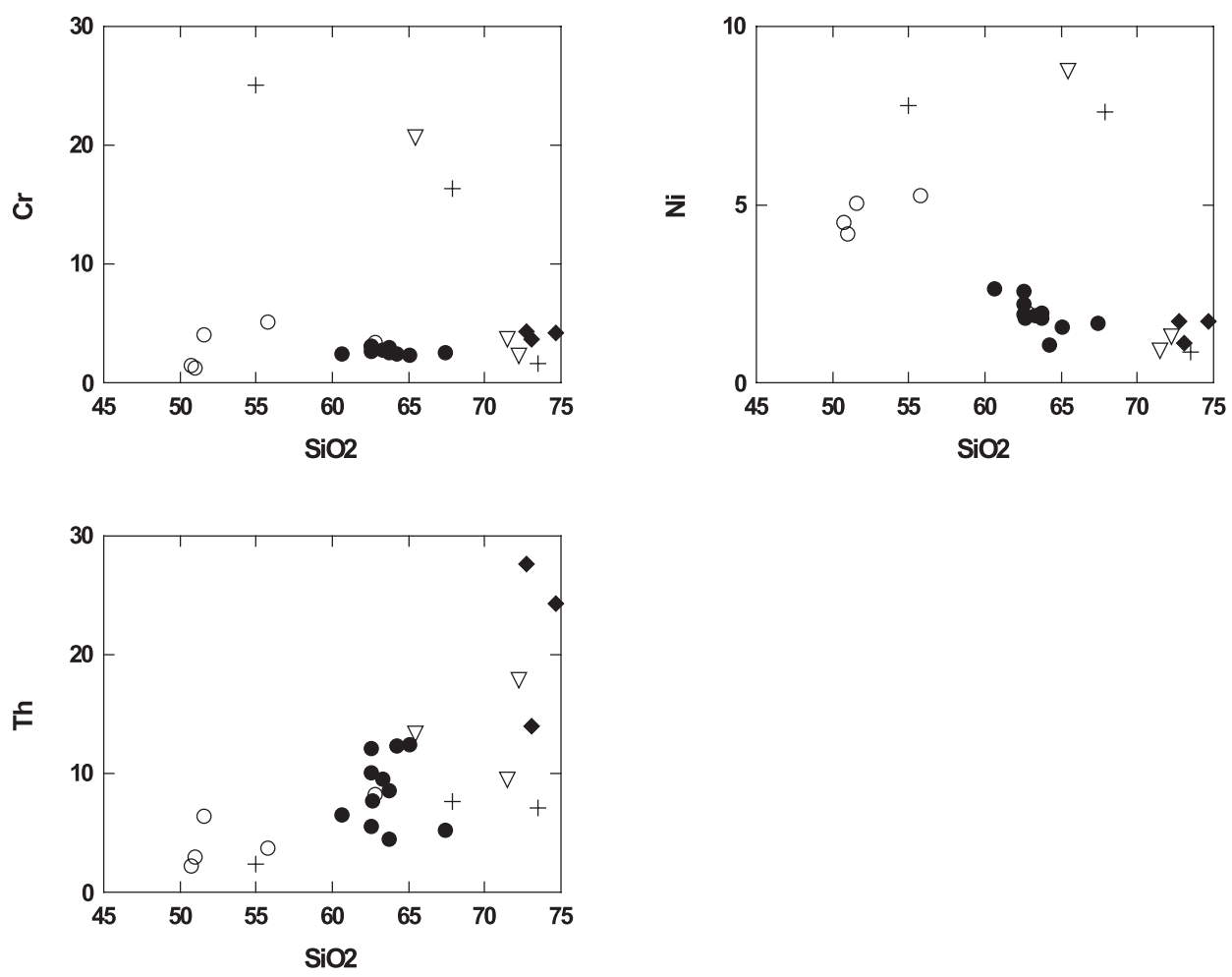

Figura 7C. Diagramas de Harker das rochas do Complexo Aimorés. Óxidos em \% em peso; outros elementos em ppm. Simbologia: $+=$ embasamento; $\mathbf{0}=$ hiperstênio monzodioritos; $\bullet=$ charnockitos; $\bullet$ granada-granitos; $\nabla=$ enclaves.

outros (Figuras $8 \mathrm{~B}$ e 8C) e definem agrupamentos distintos para cada conjunto de rochas estudadas, mostrando por um lado a afinidade geoquímica de amostras do mesmo grupo e, por outro, as descontinuidades existentes entre eles.

Os espectros dos elementos terras raras (ETR), normalizados em relação aos valores do condrito (Boynton, 1984), para as diferentes faciologias analisadas, mostram conteúdos totais em terras raras mais elevados nos monzodioritos e nos charnockitos do que nos granada-granitos, com os enclaves mostrando comportamento intermediário. Nota-se, para as diferentes faciologias, um fracionamento geral dos ETR, que é mais acentuado para os elementos terras raras leves (ETRL) (Figura 9A). Nos monzodioritos, o fracionamento dos ETRL é mais acentuado do que dos elementos das terras raras pesadas (ETRP), e apresentam uma fraca anomalia negativa de Eu. Os charnockitos apresentam comportamento semelhante, porém com fracionamento ligeiramente menor nos ETRL. Os Granada-Granitos apresentam comportamento dos ERTL similar aos charnockitos, porém são mais fracionados nos ETRP e com anomalia negativa de Eu mais acentuada. Os enclaves mostram fracionamento levemente mais acentuado em
ETRL e levemente menor em ETRP, com um deles exibindo uma anomalia levemente negativa de Eu e o outro, levemente positiva. Além disso, apresentam fracionamento ligeiramente mais acentuado em ETRP.

Nos diagramas multielementos, normalizados em relação aos Ocean Ridge Granites (ORG), de Pearce, Harris e Tindle (1984) (Figura 9B), as diferentes suítes analisadas mostram um enriquecimento em elementos LILE (elementos litófilos de grande raio iônico), especialmente $\mathrm{K}, \mathrm{Rb}$ e $\mathrm{Ba}$, e com fracas anomalias negativas em $\mathrm{Nb}$ e $\mathrm{Y}$, positivas em $\mathrm{Sm}$ e $\mathrm{Ba}$ (monzodioritos). O espectro dos LILE é ligeiramente diferente para os monzodioritos e para os granada-granitos e nota-se ainda uma anomalia negativa em Ba para o enclave. Internamente, verifica-se ainda um enriquecimento em HFS (elementos de alto potencial iônico) nos monzodioritos e charnockitos.

No diagrama de $\mathrm{MgO} v s$. o índice de saturação em alumina (Figura 10A), de Bilal e Fonteilles (1991), grande parte das amostras estudadas situa-se na curva de tendência das suítes subalcalinas e alcalinas, enquanto os granada-granitos seguem a curva de tendência das suítes cálcio-alcalinas. 

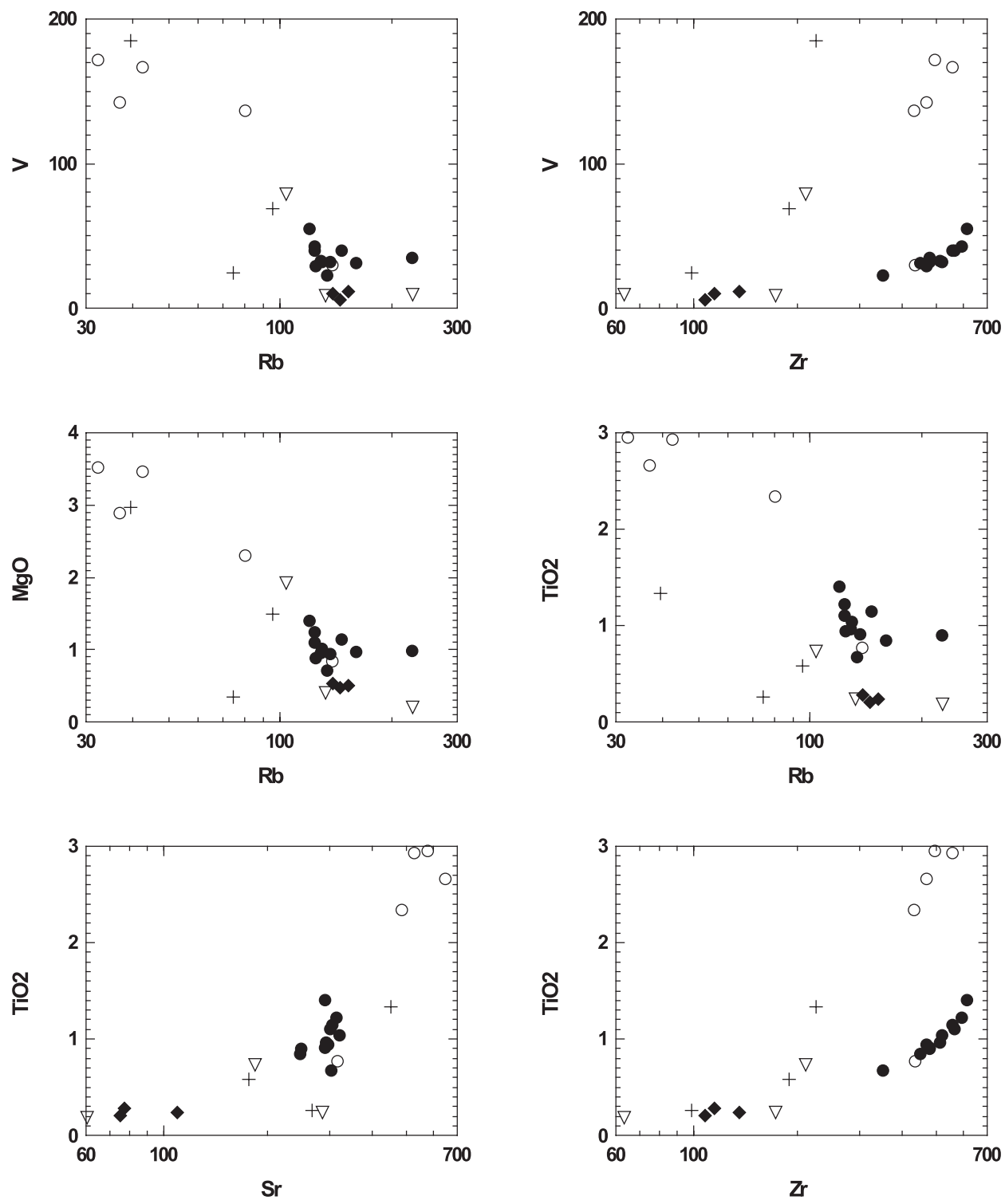

Figura 8. Diagramas de variação de elementos incompatíveis vs. elementos compatíveis. Legenda como na Figura 3.

No diagrama de discriminação de ambiente tectônico de Batchelor e Bowden (1985), os monzodioritos situam-se no campo de granito de soerguimento pós-colisional, os charnockitos, no campo tardi-orogênico, os leucogranitos, no campo sin-colisional, as encaixantes, no campo pré-colisional, enquanto os enclaves situam-se desde o campo pré-colisional até tardi-orogênico (Figura 10B).

Os diagramas triangulares ACNK*200-Zr- FMMT*30 e $\mathrm{Rb} / 20$ - $\mathrm{Ba} / \mathrm{Sr}$-FMMT mostram boa correlação dos ferro- magnesianos com o aumento da saturação em alumina e do teor em Rb (Figuras 10C e 10D). A Figura 10C mostra alinhamentos distintos para os charnockitos, hy-monzodioritos e granada-granitos, com estes últimos seguindo o alinhamento dos enclaves e das amostras do embasamento. Na Figura 10D, ao contrário, nota-se alinhamento contínuo das amostras, ressaltando-se, no entanto, teores mais baixos em Rb nos hy-monzodioritos (32 - $80 \mathrm{ppm}$ ) e mais altos nos charnockitos e granada-granitos (entre 120 e 227 ppm), 

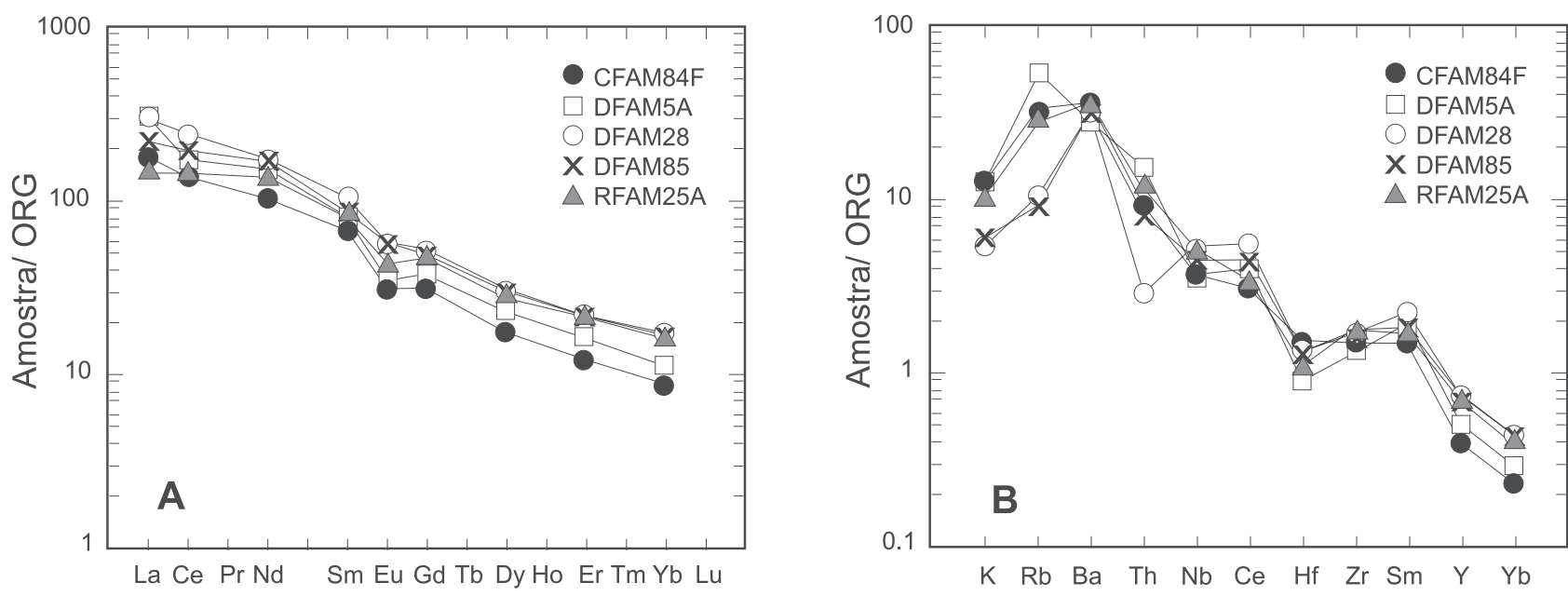

Figura 9. A. Espectros de elementos terras raras normalizados segundo padrão do condrito de Boynton (1984), para as diferentes unidades do Complexo Aimorés. B. Padrão de distribuição de elementos incompatíveis para as diferentes unidades do complexo, com normalização segundo o padrão dos Ocean Ridge Granites (ORG) de Pearce, Harris e Tindle (1984). Legenda como na Figura 4. Os valores utilizados na normalização do condrito são: $\mathbf{L a}=0,31 ; \mathbf{C e}=0,8080$; $\operatorname{Pr}=0,1220 ; \mathbf{N d}=0,6 ; \mathbf{S m}=0,1950 ; \mathbf{E u}=0,0735 ; \mathbf{G d}=0,2590 ; \mathbf{T b}=0,0474 ; \mathbf{D y}=0,3220 ; \mathrm{Ho}=0,0718$; $\mathbf{E r}=0,21 ; \mathbf{T m}=0,0324 ; \mathbf{Y b}=0,2090 ; \mathbf{L u}=0,0322$.

situação esta que é inversa para o Ba e Sr (ver Tabela 2), mostrando o papel desempenhado inicialmente pelo plagioclásio durante a cristalização magmática e depois pelo feldspato de potássio.

Nos diagramas de discriminação de ambientes tectônicos, propostos por Pearce, Harris e Tindle (1984), observa-se que os monzodioritos e charnockitos situam-se de maneira geral no campo de granitos intraplaca, enquanto os leucogranitos, os enclaves e as encaixantes ocupam o campo dos granitos de arco vulcânico e sin-colisionais (Figuras 11A e 11B). Em relação ao novo diagrama de Pearce (1996), os charnockitos, os granada-granitos e os enclaves situam-se no campo dos granitos pós-colisionais (Figura 11A).

\section{DISCUSSÃO}

As rochas estudadas apresentam três intervalos distintos em $\mathrm{Si}_{2}$ : hy-monzodioritos, entre 50,73 e $55,78 \%$, charnockitos, entre 60,69 e $67,43 \%$ e granada-granitos, entre 72,7 e 74,65\%. Comparativamente, os hy-monzodioritos são mais fortemente metaluminosos (A/CNK entre 0,72 a $0,91)$, possuem caráter alcalino e conteúdos mais elevados em $\mathrm{TiO}_{2}(2,33-2,94 \%)$ e $\operatorname{Mg} 0(2,3-3,51 \%)$, e mais baixos em $\mathrm{K}_{2} 0$ (2,19 - 2,84\%) e Rb (32 - 80 ppm). Os granada-granitos são peraluminosos (A/CNK entre 1,11 e 1,16$)$ e subalcalinos, sendo mais enriquecidos em $\mathrm{K}_{2} 0(5,34-5,90 \%)$ e fortemente empobrecidos em $\mathrm{Ti}_{2}(0,24-0,28 \%), \mathrm{Mg} 0$ $(0,47-0,53 \%)$ e $\mathrm{Zr}(108-135$ ppm). Os charnockitos são metaluminosos (A/CNK entre 0,91 e 1,0) e subalcalinos, diferenciando-se dos monzodioritos pelos conteúdos mais elevados em K e Rb, e mais baixos em Ti e Mg, e dos granada-granitos, por conteúdos mais elevados nestes últimos elementos, juntamente com o $\mathrm{Ba}$ e $\mathrm{Zr}$, sendo ainda mais baixos em K.

Nos diagramas de Harker, as rochas estudadas exibem comportamento semelhante para vários elementos durante a diferenciação magmática, como enriquecimento em metais alcalinos $(\mathrm{K}, \mathrm{Rb})$, empobrecimento dos alcalinos terrosos $(\mathrm{Mg}, \mathrm{Ca}$ e $\mathrm{Sr})$, dos elementos de transição $(\mathrm{Fe}, \mathrm{Ti}$, $\mathrm{V}, \mathrm{Sc}$ ) e dos HFS (Zr, Nb e Y). No entanto, elas se alinham de forma consistente nos diagramas em três grupos com tendências distintas (Hy-monzodioritos, Charnockitos e Granada-granitos), sugerindo uma evolução geoquímica independente e sem vínculo cogenético entre os grupos, conforme sugerido pelo comportamento do $\mathrm{Fe}, \mathrm{Na}$, $\mathrm{Zr}, \mathrm{Nb}, \mathrm{Y}$ e Th, havendo mesmo elementos com tendências divergentes, como Al, $\mathrm{Rb}$ e $\mathrm{Ba}$ (Figura 7).

$\mathrm{O}$ empobrecimento em $\mathrm{Fe}, \mathrm{Mg}$ e $\mathrm{Mn}$ nos Hy-monzodioritos e Charnockitos ressalta o efeito da cristalização magmática de minerais máficos (piroxênio, anfibólio e biotita), enquanto o empobrecimento em $\mathrm{Ca}$ e $\mathrm{Sr}$ reflete a cristalização do plagioclásio, conforme sugerido também no diagrama da Figura 10D, onde este processo é acompanhado ao mesmo tempo pelo empobrecimento em $\mathrm{Ba}$ e pela razão $\mathrm{Ba} / \mathrm{Sr}$, passando também a ser importante a cristalização de feldspato de potássio nos charnockitos e gra- 


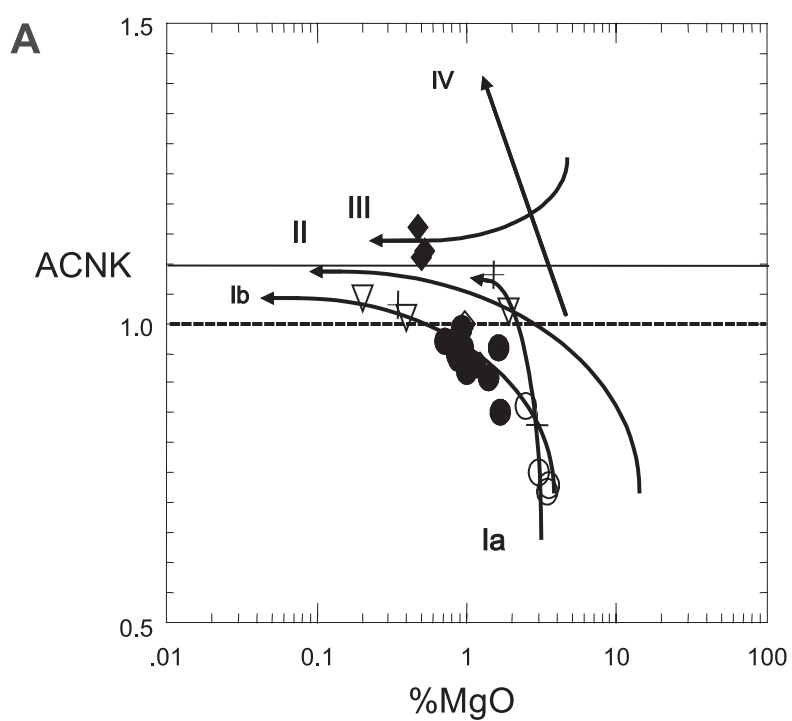

C ACNK 200

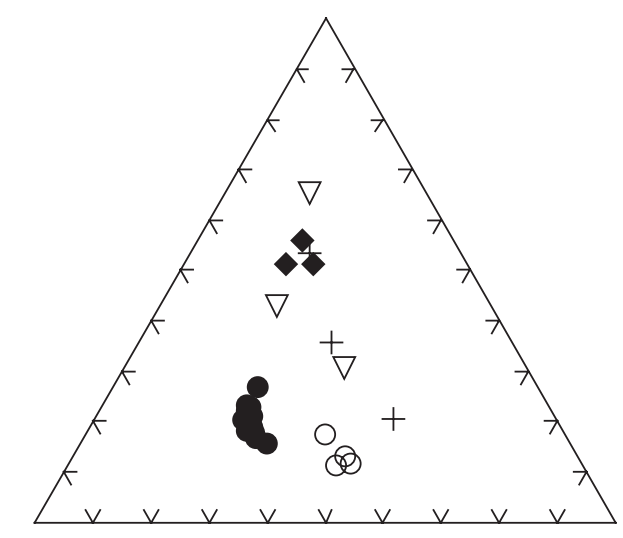

Zr

$\mathrm{FMMT}^{\star 30}$
B

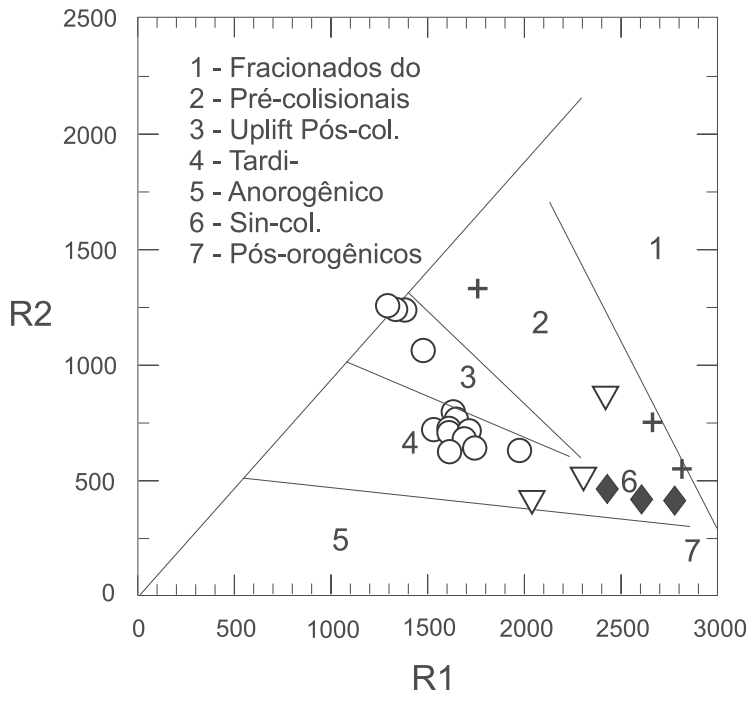

D $\quad \mathrm{Rb} / 20$

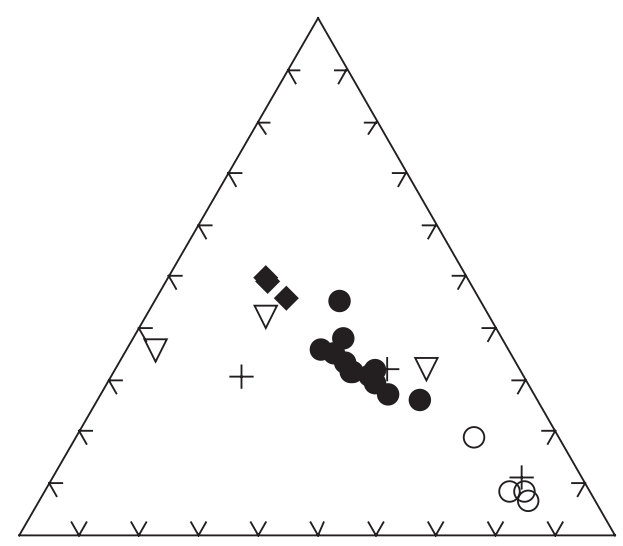

$\mathrm{Ba} / \mathrm{Sr}$
FMMT

Figura 10. A. Diagrama $\mathrm{MgO}$ vs. $\mathrm{ACNK}(\mathrm{ACNK}=\mathrm{Al} 2 \mathrm{O} 3 /(\mathrm{CaO}+\mathrm{Na} 2 \mathrm{O}+\mathrm{K} 2 \mathrm{O})$ (em moles) de Bilal e Fonteilles (1991) para as diferentes unidades do Complexo Aimorés, onde: I. suítes subalcalinas a alcalinas; II. suíte cálcio-alcalina do batólito de Moruya, do Lachlan Fold Belt, Austrália; III. suíte tipo-S, do maciço de Kosciusko do Lachlan Fold Belt, Austrália; IV. suíte magnésio-potássica. B. Diagrama R1 $(\mathrm{R} 1=4 \mathrm{Si}-11(\mathrm{Na}+\mathrm{K})-2(\mathrm{Fe}+\mathrm{Ti}))$ vs. $\mathrm{R} 2(\mathrm{R} 2=6 \mathrm{Ca}+2 \mathrm{Mg}+\mathrm{Al})$ de Batchelor e Bowden (1985). C. Diagrama Zr-FMMT*30-ACNK*200, $\left(\mathrm{FMMT}=\mathrm{Fe}_{2} \mathrm{O}_{3+}+\mathrm{MgO}+\mathrm{MnO}+\mathrm{TiO}_{2}\right)$. D. Diagra$\mathrm{ma} \mathrm{Ba} / \mathrm{Sr}-\mathrm{FMMT}-\mathrm{Rb} / 20$. Legenda: $\bullet=$ charnockito; $=$ granada-granito; $\mathbf{0}=$ monzodioritos; $+=$ hiperstênio monzodiorito; $\nabla$ = quartzo monzodiorito.

nada-granitos. De forma análoga, o empobrecimento em HFS (elementos de alto potencial iônico) reflete a cristalização fracionada de fases acessórias como zircão e apatita (Figura 7).

A boa correlação de duas amostras de enclave (EF 27, EF 84), nos diagramas de Harker com as rochas mais evoluídas do complexo (Granada-Granitos), sugere avançado grau de interação química do seu magma, o que é compa- tível com o estágio progressivo de assimilação evidenciado em muitos enclaves. Um enclave (GF 9) de composição intermediária $(65,43 \%)$ não segue esse mesmo tipo de comportamento.

A diferença de comportamento das amostras das encaixantes, em vários dos diagramas de Harker confeccionados ( $\mathrm{Ca}, \mathrm{Mg}, \mathrm{K}, \mathrm{Rb}, \mathrm{Ba}, \mathrm{Nb}, \mathrm{Y}$ e $\mathrm{Zr}$ ), afasta qualquer tipo de relação com as amostras do complexo (Figura 7). 

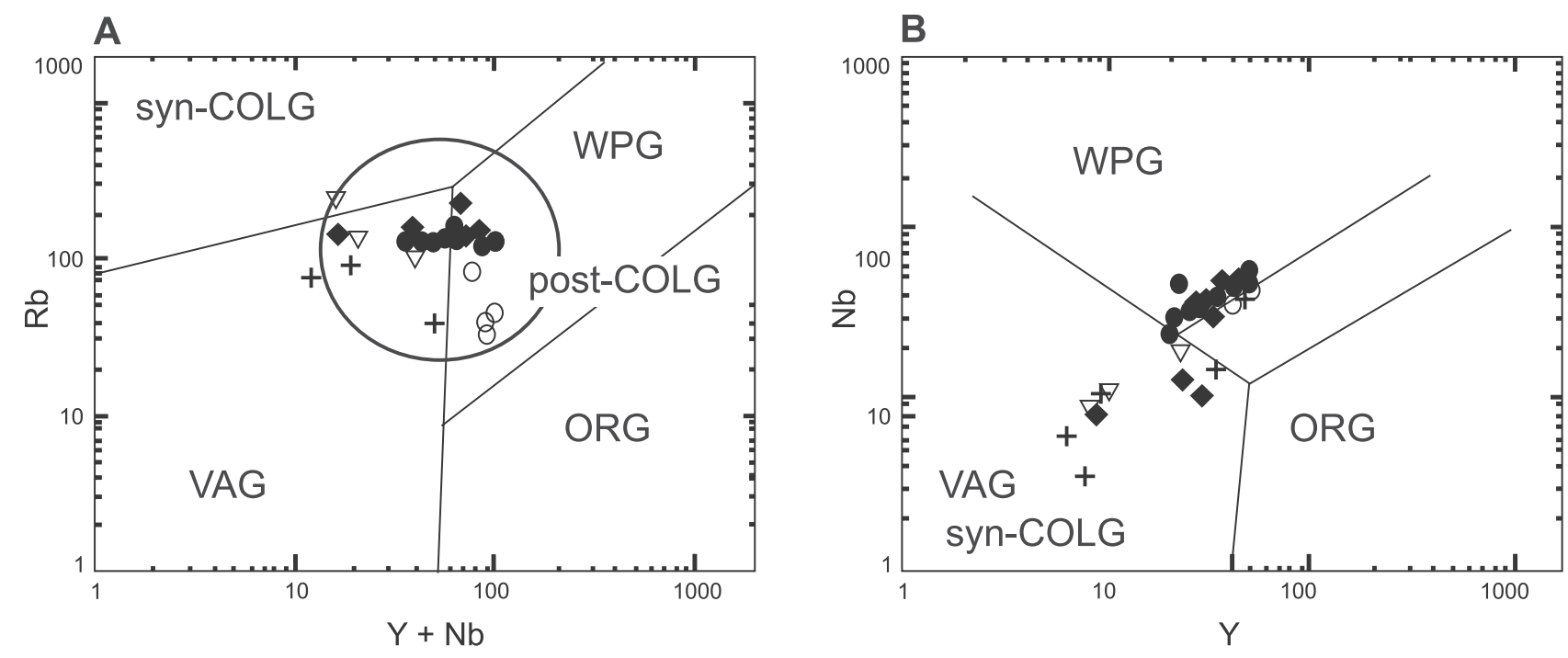

Figura 11. Diagramas de discriminação de ambientes tectônicos para rochas graníticas propostos por Pearce, Harris e Tindle (1984) e Pearce (1996). Legenda: syn-COLG = granitos sin-colisionais; VAG = granitos de arco vulcânico; WPG = granitos intrapla; ORG = granitos orogênicos; post-COLG = granitos pós-colisionais. Simbologia: como na Figura 7.

Os diagramas de elementos incompatíveis vs. compatíveis (Figura 8) ressaltam diferenças entre os grupos de rochas estudadas e mostram em geral a mesma tendência de evolução geoquímica para cada uma deles. Isto sugere que cada uma delas represente séries magmáticas distintas, porém com interações entre elas, particularmente entre os magmas dos enclaves ácidos e dos granada-granitos.

O comportamento semelhante dos espectros das terras raras leves nas diferentes faciologias pode ser explicado pela cristalização precoce de fases acessórias contendo apatita e allanita (nos charnockitos), que incorporam elementos tais como $\mathrm{La}$ e $\mathrm{Ce}$, e respondem pelo fracionamento dos mesmos já na fase inicial da cristalização magmática. $\mathrm{O}$ fracionamento mais acentuado das terras raras pesadas nos leucogranitos pode ser explicado pela presença de granada no magma, o que é compatível com sua presença na rocha com valores modais ao redor de $3 \%$ (Tabela 1 ).

Os diagramas multielementos ressaltam a semelhança entre os espectros dos charnockitos e monzodioritos, diferenciando-se este último pelos teores mais baixos em elementos LILE e pela presença de uma anomalia positiva em $\mathrm{Ba}$. Os granada-granitos e os enclaves diferenciam-se pelos conteúdos mais baixos em elementos HFS e pela anomalia negativa em $\mathrm{Ba}$.

Nos diagramas tectônicos (Pearce, Harris, Tindle, 1984; Pearce, 1996), as rochas do Complexo Aimorés discriminam-se como de ambiente intra-placa e pós-colisional ou ainda de ambiente de soerguimento pós-colisional e tardi-orogênico (Batchelor e Bowden, 1985), com os leu- cogranitos situando-se no campo de granito sin-colisional dos últimos autores.

O conteúdo elevado em $\mathrm{HfO}_{2}(\sim 1,8 \%)$ nos zircões dos Granada-Granitos do Complexo Aimorés refletem contribuição crustal e condições de baixa temperatura $\left(\sim 650^{\circ} \mathrm{C}\right)$ para geração do magmatismo (Pupin, 1992), sendo isto corroborado pelos teores em $\mathrm{Th} \mathrm{O}_{2}$ inferiores a $2.000 \mathrm{ppm}$ e de $\mathrm{UO}_{2}$ abaixo de $1.000 \mathrm{ppm}$ (Mello, 2000).

$\mathrm{O}$ modelo petrológico aqui proposto considera pelo menos três estágios principais de geração de magmas: o primeiro é relacionado com a intrusão de um magma básico de origem mantélica na base da crosta inferior, o segundo, com a fusão dessa crosta pelo calor induzido pelo magma básico e geração de um magma intermediário anidro (charnockítico), e o terceiro, com a fusão de porções mais elevadas desta mesma crosta e geração do magma ácido (granada-granito).

Os charnockitos de Aimorés, em comparação com os do Complexo Várzea Alegre, mostram conteúdos relativamente mais elevados em $\mathrm{Si}_{2}(60,69-67,43 \%$, contra $53,90-64,9 \%), \mathrm{K}_{2} 0(3,88-5,79 \%$, contra $2,02-4,14 \%)$ e $\mathrm{Rb}$ (124 - $227 \mathrm{ppm}$, contra 36 - $110 \mathrm{ppm})$, e mais baixos em $\mathrm{Ti}_{2}(0,67-1,4 \%$, contra $0,78-1,97 \%), \operatorname{Mg} 0(0,71-$ $1,39 \%$, contra $0,99-3,70 \%)$, Ba (1.365 - 1.842 ppm, contra $1.070-3.400 \mathrm{ppm}$ ), sendo igualmente meta-aluminosos e subalcalinos (Mendes et al., 2005).

Os valores de pressão (baseados na distribuição do Al no anfibólio cálcico) fornecidos pelos charnockitos do Complexo Aimorés (entre 4,4 $\pm 0,6$ kbar e 5,8 $\pm 0,6$ kbar) 
são mais baixos do que os obtidos para os charnockitos dos complexos Lagoa Preta (entre 5,8 $\pm 0,6$ kbar e 6,6 \pm 0,6 kbar), Várzea Alegre e Santa Angélica (entre 5,7 0,6 kbar a 11,47 $\pm 0,6$ kbar) (Mendes, Wiedemann, McReath, 1999), indicando posicionamento em nível crustal mais raso (Wiedemann et al., 2002; Mello et al., 2007).

A relação dos complexos similares ao Aimorés com a orogênese brasiliana é uma questão ainda não muito bem estabelecida. Alguns autores classificam como tardi-orogênicos (Medeiros, Wiedemann-Leonardos, Vriend, 2000; Pedrosa-Soares e Wiedemann-Leonardos, 2000; Wiedemann et al., 2002), outros, como tardi a pós-orogênicos ou tardi a pós-tectônicos (Siga Jr., 1986; Wiedemann, 1993; Bilal et al., 1998; Mendes, Wiedemann, McReath, 1999; Mendes et al., 2005). As idades U/Pb restringem o magmatismo para o intervalo de 520 e 495 Ma e mostram que ele ocorreu cerca de 70 a 90 Ma após o pico do metamorfismo regional (Sölner et al., 1987; Nalini, 1997; Nalini et al., 2000; Pedrosa-Soares e Wiedemann-Leonardos, 2000, dentre outros) e os granitos sin-colisionais (suíte G2 de Pedrosa-Soares e Wiedemann-Leonardos, 2000). Esta diferença de idade é muito mais ampla do que o intervalo de tempo (15 a $35 \mathrm{Ma}$ ) que separa os granitos pós-colisionais/orogênicos do metamorfismo regional das orogêneses Caledoniana, Hercínica, Alpina e Himalaina (Urs e Corfu, 1992; Sylvester, 1998; Bonin, 1998; Miller et al., 1999; Smith, Chamberlain, Zeitler, 1994; Streule et al., 2008; Strachan, Nutman, Friderichsen, 1995; Bickle et al., 1988; Zeck e Whitehouse, 2002; Inger e Cliff, 2007; Berger e Bousquet, 2008), reforçando assim a interpretação sobre a natureza pós-orogênica do magmatismo aqui estudado, desvinculando-o, portanto, sua geração da orogênese brasiliana.

\section{CONCLUSÕES}

O comportamento geoquímico diferente das amostras estudadas em vários tipos de diagramas (Harker, triangulares, elementos incompatíveis vs. elementos compatíveis) evidencia para o Complexo Aimorés três grupos não cogenéticos de rochas: hy-monzodioritos, charnockitos e ganada-granitos. Em termos geoquímicos, o primeiro grupo mostra-se menos evoluído, enquanto o último é mais evoluído. $\mathrm{O}$ enriquecimento em elementos incompatíveis $(\mathrm{K}$, $\mathrm{Rb}, \mathrm{Ba}, \mathrm{Nb}, \mathrm{Ce}, \mathrm{Hf}, \mathrm{Zr}$, ETR) e de ETRL em relação às ETRP sugerem contribuição crustal para o magmatismo. $\mathrm{O}$ decréscimo em $\mathrm{V}, \mathrm{Mg}$ e Ti com o aumento em $\mathrm{Rb}$ pode ser o resultado da cristalização fracionada ou de contaminação promovida pela mistura de magmas, conforme sugerido pelos alinhamentos paralelos das amostras nos diagramas com $\mathrm{V} v s$. $\mathrm{Rb}$ e $\mathrm{TiO}_{2} v s$. Zr, e também no diagrama triangular $\mathrm{Rb} / 20-\mathrm{Ba} / \mathrm{Sr}-\mathrm{FMMT}$ (Figuras 7 e 10D).
Os charnockitos estudados, em comparação com os de Várzea Alegre, são resultantes de magmas mais evoluídos e provavelmente com maior interação crustal, uma vez que mostram conteúdos relativamente mais elevados em Si, $\mathrm{K}$ e $\mathrm{Rb}$, e mais baixos em $\mathrm{Ti}, \mathrm{Mg}$ e $\mathrm{Ba}$.

Os diagramas de discriminação de ambientes tectônicos indicam magmatismo pós-colisional de ambiente intraplaca, confirmando assim trabalhos anteriores sobre complexos similares da região. No entanto, as idades $\mathrm{U} / \mathrm{Pb}$ entre 520 e 495 Ma, disponíveis para esses complexos, indicam que a sua geração ocorreu cerca de 80 Ma após o pico do metamorfismo regional, já em regime tectônico extensional, desvinculando, portanto, este magmatismo do regime tectônico compressivo anterior (regime orogênico), sugerindo tratar-se de um magmatismo de natureza pós-orogênica, de forma análoga ao que se observa nas cadeias modernas, fanerozoicas, onde o magmatismo pós-orogênico possui, em relação ao magmatismo orogênico, uma diferença temporal bem menor (entre 15 a $35 \mathrm{Ma}$ ).

As estruturas magmáticas observadas no Complexo Aimorés estão associadas ao posicionamento do corpo, enquanto as estruturas de deformação no estado sólido associam-se a um evento deformacional posterior, relacionado provavelmente ao colapso do complexo. A presença de contatos transicionais e hibridização de magmas, com exceção dos Granada-Granitos, indica contemporaneidade entre as unidades. Os dados geotermobarométricos são compatíveis com alojamento do corpo em profundidades ao redor de $20 \mathrm{~km}$.

\section{AGRADECIMENTOS}

Os autores agradecem ao Instituto de Geociências da USP, à Universidade Federal Rural do Rio de Janeiro, à Escola de Minas de Saint-Etienne (França), ao acordo CAPES-COFECUB (Projeto 158/94) e ao CNRS-UMR6425, bem como ao CNPq (Proc. 300423/82-9) pela concessão de uma bolsa de Produtividade em Pesquisa a um dos autores (R. Machado). Os autores agradecem também a três revisores anônimos pela contribuição na melhoria do manuscrito.

\section{REFERÊNCIAS}

ALMEIDA, F. F. M.; AMARAL, G.; CORDANI, U. G.; KAWASHITA, K. The precambrian evolution of the south american cratonic margin south of Amazon river. In: NAIRN, E. M.; STEHLI, F. G. (Ed.). The ocean basins and margins. New York: Plenun, 1973. p. 411-446.

ALMEIDA, F. F. M.; HASUI, Y. O Pré-Cambriano do Brasil. Edgar Blücher, São Paulo, p. 282-307, 1984. 
BATCHELOR, R. A.; BOWDEN, P. Petrogenetic interpretation of granitoids series using multicationic parameters. Chemical Geology, v. 48, p. 43-55, 1985.

BERGER, A.; BOUSQUET, R. Subduction related metamorphism in the Alps: review of isotopic ages based on petrology and their geodynamic consequences. Geological Society, London, Special Publications, v. 298, p. 117-144, 2008.

BICKLE, M. J.; WICKHAN, S. M.; CHAPMAN, H. J.; TAYLOR, H. P. A strontium, neodymium and oxigen isotope study of hydrothermal metamorphism and crustal anatexis in the Trois Seigneurs Massif, Pyrenees, France. Contributions Mineralogy and Petrology, v.100, n. 4, p.399-417, 1988.

BILAL, E.; FONTEILLES, M. Les granites anorogéniques de la région de Goiás (Brèsil). In: Seance Speciale de la societe geologique de france a la memoire de j. Lameyre. Résumés. Paris, 1991. p. 25.

BILAL, E.; HORN, H.; NALINI, H. A.; MELLO, F. M.; CORREIA-NEVES, J. M.; GIRET, A.; MOUTTE, J.; FUZIKAWA, K.; FERNANDEZ, M. L. S. The Neoproterozoic granitoid suites in South-easthern Brazil. Revista Brasileira de Geociências, v.30, n.1, p. 51-54, 2000.

BILAL, E.; NALINI JR., H.; HORN, H. A.; CORREIANEVES, J. M.; GIRET, A.; FUZIKAWA, K.; FERNANDES, M. L.; MELLO, F. M.; MOUTTE, J. Neoproterozoic granitoid suites of Rio Doce Region, Brazil. In: INTERNATIONAL CONFERENCE ON BASEMENTTECTONICS, 14., 1998, Ouro Preto. Abstracts... Ouro Preto, 1998. p. 41-43.

BONIN, B. Orogenic to non-orogenic magmatic events: overview of the Late Variscan magamatic evolution of the Alpine belt. Journal Earth Sciences, v. 7, p.133-143,1998.

BOYNTON, W.V. Cosmochemistry of the rare earth element: meteorite studies. In: HENDERSON, P. (Ed.) Rare Earth Element Geochemistry. Amsterdan: Elsevier, 1984. p. 63-114.

BRAJNIKOV, B. Matériaux pour servir a la carte géologique de Êtat d'Espirito Santo. Vitória: Imprensa Oficial, 1955.

CAMPOS NETO, M. C.; FIGUEIREDO, M. C. H. The Rio Doce orogeny, Southeastern Brazil. Journal of South American Earth Sciences, v. 8, n. 2, p. 143-162, 1995.
FÉBOLI, W. L.; RIBEIRO, J. H.; HEINECK, C. A.; RAPOSO, F. O.; SOUZA, E. C. Estratigrafia. In: FÉBOLI, W. L. (Org.) Programa Levantamentos Geológicos Básicos - Domingos Martins - Folha SF 24-V-A-III. Brasília: DNPM-CPRM, 1993. p. 27-101.

FIGUEIREDO, M. C.; CAMPOS NETO, M. Geochemistry of the Rio Doce magmatic arc, southeastern Brazil. Anais $d a$ Academia Brasileira de Ciências, v. 65, n. 1, p. 63-81, 1993.

FONTES, C. Q.; NETTO, C.; COSTA, M. R. A.; BALTAZAR, O. F.; SILVA, S. L.; VIEIRA, V. S. Projeto Jequitinhonha. Belo Horizonte: DNPM/CPRM, 1978. (Relatório do Arquivo Técnico da DGM, v. 1, n. 2787).

GUIMARÃES, D. Os charnoquitos do Espírito Santo. Boletim Instituto Técnico Industrial, Belo Horizonte, n. 23, p. 1-30, 1956.

HARRIS, N. B. W.; PEARCE, J. A.; TINDLE, A. G. Geochemical characteristics of collision-zone magmatism. In: COWARD, M. P.; RIES, A. C. (Ed.) Collision Tectonics. Oxford: Published for the Geological Society by Blackwell Scientific, 1986. p. 67-81. (Geological Society Special Publication, n. 19).

HASUI, Y.; CARNEIRO, C. D. R.; COIMBRA, A. M. The Ribeira folded belt. Revista Brasileira de Geociências, v. 5 , n. 4 , p. 257-266, 1975.

INGER, S.; CLIFF, R. A. Timing of metamorphism in the Tauern Window, Eastern Alps: Rb-Sr ages and fabric formation. Journal of Metamorphic Geology, v. 12, n. 5, p. 695-702, 2007.

IRVINE, T. N.; BARAGAR, W. R. A. A guide to the chemical classification of the common volcanic rocks. Canadian Journal of Earth Sciences, v. 8, n. 5, p. 523-548, 1971.

KARNIOL, T. R.; MACHADO, R. Análise geométrica e cinemática de um segmento da região do baixo vale do Rio Doce entre Aimorés (MG e Colatina (ES). Revista Brasileira de Geociências, v. 34, n. 3, p. 373-382, 2004.

KARNIOL, T. R.; MACHADO, R. Análise microestrutual e de eixo-C de quartzo na seção Aimorés (MG e Colatina (ES). Revista Brasileira de Geociências, v. 35, n. 4, p. 493-502, 2005.

LUDKA, I. P.; WIEDEMANN, C. M.; TÖFNER, C. On the origino of incompatible element enrichmente in 
the Venda Nova pluton, Espírito Santo. Journal South American Earth Sciences, v. 11, p. 473-486,1998.

MANIAR, P. D.; PICCOLI, P. M. Tectonic discrimination of granitoids. Geological Society of American Bulletim, v. 101, p. 635-643, 1989.

MARTINS, V. T. Geologia isotópica do plutonismo Neoproterozóico da Faixa Araçuaí, região nordeste de Minas Gerais. 2000. 187 f. Dissertação (Mestrado) Instituto de Geociências, Universidade de São Paulo, São Paulo, 2000.

MARTINS, V. T.; TEIXEIRA, W.; NOCE, C. M.; PEDROSA-SOARES, A. C. Sr and Nd characteristics of Brasiliano/Pan-African granitoid plutons of the Araçuaí Orogen, Southeastern Brazil: tectonic implications. Gondwana Research, v. 7 , n. 1, p. 75-89, 2004.

MEDEIROS, S. R.; WIEDEMANN, C. M.; MENDES, J. $\mathrm{C}$. Evidence of mingling between contrasting magmas in a deep plutonic environment: the example of Varzea Alegre, in the Pan-Africa/Brasiliano Mobile Belt in Brazil. Anais da Academia Brasileira de Ciências, v. 73, p. 99-119, 2001.

MEDEIROS, S. R.; WIEDEMANN-LEONARDOS, C. M,; VRIEND, S. Post-collisional multisage magmatism in the Ribeira Mobile Belt: Geochemical and isotopic study of the Varzea Alegre Intrusive Complex, Espírito Santo, Brazil. Revista Brasileira de Geociências, v. 30, n. 1, p. 30-34, 2000.

MELLO, F. M. Litogeoquímica e Química Mineral do Maciço Charnockítico Aimorés-MG. 2000, 167 f. Tese (Doutorado) - Instituto de Geociências, Universidade de São Paulo, São Paulo, 2000.

MELLO, F. M.; MACHADO, R.; BILAL, E.; BARBOSA, V. S. Geotermobarometria de Suites dos Maciços Intrusivos Aimorés e Lagoa Preta-MG. In: SIMPÓSIO DE GEOLOGIA DE MINAS GERAIS, 14/SIMPÓSIO DE GEOLOGIA DO SUDESTE, 10., 2007, Diamantina. Boletim de Resumos... Diamantina: SBG, 2007, p. 41.

MENDES; J. C.; McREATH, I.; WIEDEMANN; C. M.; FIGUEIREDO, M. C. H. Charnoquitóides do maciço Várzea Alegre: um novo exemplo do magmatismo cálcio-alcalino de alto K no arco magmático do, Espírito Santo. Revista Brasileira de Geociências, v. 27, n. 1, p. 13-24, 1997.

MENDES; J. C.; MEDEIROS, S. R.; McREATH, I.; CAMPOS, C. M. P. Cambro-Ordovician magmatism in
SE Brazil: U-Pb and Rb-Sr ages, combined with $\mathrm{Sr}$ and $\mathrm{Nd}$ isotopic data of charnockitic rocks from the Varzea Alegre complex. Gondwana Research, v. 8, n. 3, p. 337-345, 2005.

MENDES; J. C.; WIEDEMANN; C. M.; McREATH, I. Conditions of Formation of Charnockitic Magmatic Rocks from the Várzea Alegre Massif, Espírito Santo, Southeastern Brazil. Revista Brasileira de Geociências, v. 29 , n. 1, p. 47-54, 1999.

MIDDLEMOST, E. A. K. Naming materials in the magma/igneous rock system. Earth Science Review, v. 37, p. 215-224, 1994.

MILLER, G.; SCHUSTER, R.; KLÖSTZLI, U.; FRANK, W.; PURTSCHELLER, F. Post-Collisional potassic and ultrapotassic magmatism in SW Tibet: geochemical and $\mathrm{Sr}-\mathrm{Nd}-\mathrm{Pb}-\mathrm{O}$ isotopic constraints for mantle source characteristic and petrogenesis. Journal of Petrology, v. 40, n. 9, p.1399-1424, 1999.

MUNHÁ, J. M. U.; CORDANI, U. G.; TASSINARI, C. C. G.; PALÁCIOS, T. Petrologia e termocronologia de gnaisses migmatíticos da Faixa de Dobramentos Araçuaí (Espírito Santo, Brasil). Revista Brasileira de Geociências, v. 35, n. 1, p.123-134, 2005.

NALINI JR., H. A. Caractérisation des suites magmatiques néoproterozoïques de la région de Conselheiro Pena et Galiléia (Minas Gerais, Brésil). 1997. 237 f. Tese (Doutorado) - École des Minas de Saint-Etienne, SaintEtienne, França, 1997.

NALINI JR., H. A.; BILAL, E.; PAQUETTE, J. L.; PIN, C.; MACHADO, R. Geochronologie U-Pb et géochimie isotopique $\mathrm{Sr}-\mathrm{Nd}$ des granitoïdes neoproterozoiques des suites Galileia et Urucum, vallée du Rio Doce, Sud-Est du Brésil. Comptes Rendus de l'Academie dês Sciences, Paris, v. 331, p. 459-466, 2000.

NALINI JR., H. A.; MACHADO, R.; BILAL, E. Geoquímica de petrogênese da Suíte Galiléia: exemplo de magmatismo tipo-I metaluminoso pré-colisional Neoproterozóico da região do médio vale do rio Doce. Revista Brasileira de Geociências, v. 35, n. 4, p. 23-34, 2005. Suplemento.

NALINI JR., H. A.; MACHADO R.; ENDO, I.; BILAL, E. A importância da tectônica transcorrente no alojamento de granitos pré- a sincolisionais na região do vale do médio rio Doce: o exemplo das suítes graníticas Galiléia e Urucum. Revista Brasileira de Geociências, v. 38, n. 4, p. 741-742, 2008. 
NALINIJR.,H. A.; MACHADO, R.; BILAL, E. Geoquímica e petrogênese da suíte Galiléia: exemplo de magmatismo tipo-I metaluminoso pré-colisional Neoproterozóico da região do médio vale do Rio Doce (MG). Revista Brasileira de Geociências, v. 38, n. 4, p. 741-752, 2008.

NOCE, C. M.; MACAMBIRA, M. B. A.; PEDROSASOARES, A. C. Chronology of the NeoproterozoicCambrian Granitic Magmatism in The Araçuaí Belt, Eastern Brazil, based on single zircon evaporation dating. Revista Brasileira de Geociências, v. 30, n. 1, p. 25-29, 2000.

NOCE, C. M.; MACAMBIRA, M. J. B.; PEDROSASOARES, A. C.; MARTINS, V. T. S.; FERREIRA, D. C. Chronology of late proterozoic-cambrian granitic magmatism in the Araçuaí belt, eastern Brazil, based on dating by single zircon evaporation. In: SOUTH AMERICAN SYMPOSIUM ON ISOTOPE GEOLOGY,2., 1999. Córdoba, Argentina. Actas... Córdoba: SEGEMAR, 1999. p. 86-89.

O'CONNOR, J.T. A classification for quartz-rich igneous rocks based on feldspar ratios. US Geological Survey Profissional Papers, n. 525B, p.79-84, 1965.

OFFMAN, R. A.; WEBER-DIEFENBACH, K. Two zoned complexes in the Iconha region, Espírito Santo, Brazil: a geochemical characterization of an Intrusive Series. Zentralblatt für Geologie und Paläontologie, Teil I, n. 5/6, p. 903-916, 1989.

PEARCE, J. A. Sources and settings of granitic rocks. Episodes, v. 19, n. 4, p.120-125, 1996.

PEARCE, J. A.; HARRIS, N. B. W.; TINDLE, A. G. Trace elements discrimination diagrams for the tectonic interpretation of granite rocks. Journal of Petrology, v. 25, p. 956-983, 1984.

PEDROSA-SOARES, A. C.; NOCE, C. M.; ALKMIN, F. F.; SILVA, L. C.; BABINSKI, M.; CORDANI, U.; CASTAÑEDA, C. Orógeno Araçuaí: síntese do conhecimento 30 anos após Almeida 1977. Geonomos, v. 15, n. 1, p.1-16, 2007.

PEDROSA-SOARES, A. C.; NOCE, C. M.; WIEDMANNLEONARDOS, C. M.; PINTO, C. P. The Araçuaí-WestCongo Orogen in Brazil: An Overview of a Confined Orogen formed during Gondwanaland Assembly. Precambrian Research, v. 110, p. 307-323, 2001.

PEDROSA-SOARES, A. C.; WIEDMANN-LEONARDOS, C. M. Evolution of the Araçuaí Belt and its Connection to the
Ribeira Belt, Eastern Brazil. In: CORDANI, U. G.; MILANI, E.; THOMAZ-FILHO, A. (Ed.) Tectonic Evolution of South America. Rio de Janeiro: SBG, 2000. p. 265-285.

PINHEIRO, J. C. F.; BIONDI, J. C.; PINHEIRO, S. O. Granulitos e/ou Charnockitos do Cinturão Granulítico Atlântico - Maciços de Aimorés, Itapina, Itaguaçu e Itanhomi. In: CONGRESSO BRASILEIRO DE GEOLOGIA, 30., 1978, Recife, Anais... Recife: SBG, 1978 , v. 3, p. $1288-1302$.

PITCHER, W. Granite type and tectonic environment. In: HSU, K. (Ed.) Mountain Building Processes. London: New York: Academic Press, 1982. p. 19-40.

PITCHER, W. Granites and yet more granites forty years on. Geologische Rundschau, v. 76, n. 1, p. 51-79, 1987.

PITCHER, W. S. The Nature and Origin of Granite. 2. ed. London: Chapman \& Hall, 1997. 377 p.

PUPIN, J. P. Les zircons des granites océaniques et continentaux: couplage typologie-géochimie des éléments en traces. Bull. Soc. Géol. France, 163-4, p. 495-507, 1992.

SIGA JR., O. A evolução geológica da porção nordeste de Minas Gerais, com base em interpretações geocronológicas. 1986. 140 f. Dissertação (Mestrado) Instituto de Geociências, Universidade de São Paulo, São Paulo, 1986.

SILVA, J. M. R.; LIMA, M. I. C.; VERONESE, V. F.; RIBEIRO JR., R. N.; ROCHA, R. M.; SIGA JR., O. Geologia. In: Projeto Radambrasil, Folha SE.24 - Rio Doce. Rio de Janeiro: IBGE, 1987. Escala 1:1.000.000. (Levantamento de Recursos Naturais, 34).

SMITH, H. A.; CHAMBERLAIN, C. P.; ZEITLER, P. K. Timing and duration of Himalaian metamorphism within the Indian Plate, Nortwest Himalaya, Pakistan. Journal of Geology, v. 102, n. 5, p. 493-508, 1994.

SÖLLNER, F.; LAMMERER, B.; WEBERDIEFENBACH, K.; HANSEN, B. T. The brasiliano orogenesis: age determinations $(\mathrm{Rb}-\mathrm{Sr}$ and $\mathrm{U} / \mathrm{Pb})$ in the coastal mountains region of Espírito Santo, Brazil. Zentralblatt für Geologie und Palaentologie, Teil I, v. 7/8, p. 729-741, 1987.

STRACHAN, R. A.; NUTMAN, A. P.; FRIDERICHSEN, J. D. SHRIMP U-Pb geochronology and metamorphic history of the Smallefjord sequence, NE Greenland 
Caledonides. Journal of Geological Society, v. 152, n. 5, p. 779-784, 1995.

STRECKEISEN, A. How should charnockitic rocks be named? In: BELLIÈRE, J. and DUCHESNE, J. C. (Ed.) Géologie des Domaines Cristallins. Liége, Sociéte Géologique de Belgique, Centenary Volume, 1974. p. 349-360.

STREUlE, M.J. S.; SEARLE, M. P.; HORSTWOOD, M. S. A.; WATERS, D. J. Melting ang exhumation of the upper structural levels of the Greater Himalaya Sequence and Makalu granite: constraints from thermobarometry, metamorphic modeling and $\mathrm{U}-\mathrm{Pb}$ geochronology. In: HIMALAYAN-KARAKORAM-TIBET WORKSHOP, 23., 2008, India. Extended Abstracts... India, 2008, p. 162.

SYLVESTER, P. J. Post-Collision strongly peraluminous granites. Lithos, v. 45, p. 29-44, 1998.

TULLER, M. P. Geologia da Folha Colatina. In: TULLER, M. P. (Org.) Programa de Levantamentos Geológicos Básicos do Brasil, Folha SE.24-Y-C-VI - Colatina. Brasília: DNPM/CPRM, 1993. p. 3-143.

URS, S.; CORFU, F. The age and source of late Hercynian magmatism in the central Alps: evidence from precise $\mathrm{U}-\mathrm{Pb}$ ages and initial Hf isotopes. Contributions to Mineralogy and Petrology, v. 111, p. 329-344, 1992.

VIEIRA, V. S.; SOUZA, E. C.; RAPOSO, F. O.; SILVA, L. C.; HEINECK, C. A. Geologia da Folha Baixo Guandu. In: Vieira, V. S. (Org.), Programa de levantamentos geológicos básicos do Brasil, Folha SE24-Y-C-V-Baixo Guandú, Brasília: DNPM/CPRM. 1993. p. 15-134.

WIEDEMANN, C. M. The evolution of the Paleozoic, late- to post-collisional magmatic arc of the coastal mobile belt, in the state of Espiríto Santo, eastern Brazil. Anais da Academia Brasileira de Ciências, v. 65, n. 1, p. 163-181, 1993. Suplemento.

WIEDEMANN, C.; MENDES, J. C.; LUDKA, I. P. Contamination of mantle magmas by crustal contributionevidence from the Brasiliano Mobile Belt in the State of Espírito Santo, Brazil. Anais da Academia Brasileira de Ciências, v. 67, p. 279-292, 1995.

WIEDEMANN, C.; MENDES, J. C.; MOURA, J. C.; COSTA NASCIMENTO, R. C.; LUDKA, I. P. Granitoids of the Espírito Santo Magmatic Arc. In: INTERNATIONAL SYMPOSIUM ON GRANITES
AND ASSOCIATED MINERALIZATIONS, 2., 1997, Salvador. Field Guide... Salvador: Superintendencia de Geologia e Recursos Minerais, 1997. p. 57-76.

WIEDEMANN, C. M.; MEDEIROS, S. R.; LUDKA, L. P.; MENDES, J. C.; MOURA, C. J. Architecture of Late Orogenic Plutons in the Araçuaí-Ribeira Fold Belt, Southeast Brazil. Gondwana Research, v. 5, n. 2, p. 381-399, 2002.

ZECK, H. P.; WHITEHOUSE, M. J. Repeated age resetting in zircons from Hercynian-Alpine polymetamorphic schists (Beltic-Rift tectonics belt, $\mathrm{S}$. Spain) -a U-Th-Pb ion microprobe study. Chemical Geology, v. 182, p. 275-292, 2002. 
